\title{
The limits to lender of last resort interventions in emerging economies: evidence from the Gold Standard and the Great Depression in Spain
}

\author{
Enrique Jorge-Sotelo* \\ Department of Economic History \\ London School of Economics and Political Science
}

November 6, 2018

\begin{abstract}
Conventional accounts argue that Spain escaped the Great Depression because its currency was not convertible to gold. Accordingly, when a bank run ensued in 1931, the Banco de España (BdE) would have been able to lend freely as lender of last resort. Drawing on new archival data on bank balance sheets and discount window borrowing, I show that rapid currency depreciation caused by the reversal in international capital flows that started in 1928 bounded monetary authorities to a dilemma between liquidity assistance and capital mobility during the 1931 crisis. These limits to policy reaction help explain the sharp contraction in bank lending and economic activity during and after 1931.
\end{abstract}

\footnotetext{
*Aknowledgments: I am grateful to Olivier Accominotti and Stefano Ugolini for continuous support, feedback and comments. I also benefited from discussions with Thilo N.H. Albers, Miguel Artola, Yolanda Blasco, Michael Bordo, Lars Börner, Germán Forero, Daniel Gallardo, Alejandra Irigoin, Pablo MartínAceña, Elena Martínez, Chris Meissner, Cyril Milhaud, David Pavón, Vigyan D. Ratnoo, Gary Richardson, Joan Rosés and Eugene White. I also thank participants at conferences and workshops at LSE, Cambdrige, Barcelona, Helsinki, Royal Holloway, Humboldt, Carlos III de Madrid, U. Pública de Navarra, Federal Reserve Bank of St. Louis and the XVIII World Economic History Congress. Data was collected with the help of archivists Virginia García de Paredes and Gema Hernández (Banco de España), José Antonio Gutiérrez and Maite Gómez (Banco Santander), Victor Arroyo, Gorka Fuente and Borja Fernández (BBVA), Melanie Aspey (Rothschild) and Piet Clement (BIS). Funding from the Economic and Social Research Council (ESRC), Societat Econòmica Barcelonesa d'Amics del Pais (SEBAP) and the Radwan Travel and Discovery Fund (LSE) is gratefully acknowledged. All remaining errors are mine.
} 


\section{Introduction}

When most European countries returned to the gold standard during the second half of the 1920s, they limited their central banks' room for lender of last resort (LLR) interventions during banking crises. In such circumstances, monetary authorities had a hard choice to make: they could limit emergency liquidity assistance to the amounts compatible with their convertibility rules or they could ensure they provided enough assistance for the banking sector to overcome liquidity shocks. The first might imply allowing for the banking system to undergo severe liquidity pressure, while the second might force them to suspend convertibility (Eichengreen, 1992). This trade-off implied that prioritizing exchange rate stability was a major cause of banking crises during the Great Depression, contributing to the deflationary dynamics of the 1930s (Bernanke and James, 1991; James, 2002). Spain is commonly used as an illustration of this trade-off, as it operated an currency that was not convertible to gold. Accordingly, conventional accounts argue that Spain avoided the Great Depression by never being on the gold standard (Temin, 1993; Reinhart and Rogoff, 2009).

This paper revisits Spanish banking developments in the 1930s, with a specific focus on the 1931 financial crisis. I argue that the actual policy options available to Spanish monetary authorities were very limited. Because of rapid currency depreciation and growing currency mismatches in the banking system, Spain lost its monetary independence and ability to implement a fully-loaded lender of last resort intervention in 1931. Monetary authorities only regained command of monetary policy once capital controls were introduced. This delayed the intervention and limited its scope, and helps understand the sharp contraction in bank lending and economic activity that took place after April 1931. The interpretation provided in this paper contrasts significantly with the traditional account. Using the macroeconomic trilemma framework, the literature on the Great Depression usually depicts Spain as having deliberately forgone the exchange rate stability granted by a gold standard in exchange for room for discretion in monetary policy (and free capital mobility). Instead, I argue that the Spanish experience during 1931 supports recent research that questions the actual existence of a macroeconomic trilemma for emerging economies and suggests that policy options are more frequently limited to a dilemma: regardless of the exchange rate regime, when the monetary policy stance changes in the center country (the main creditor), room for monetary policy autonomy is possible only once capital controls are in place (Farhi and Werning, 2014; Rey, 2015). 
In fact, during the Interwar Period, Spanish policymakers only accepted a floating exchange rate as long as the peseta remained relatively stable or appreciated due to capital inflows (1923-1927), reflecting their aim at the reputation that came attached to a strong currency at the time (Eichengreen, 1992; Straumann, 2010). This trend, however, ended as soon as the international reversal of capital flows gained momentum after 1928 (Accominotti and Eichengreen, 2016). As soon as the peseta began to fall rapidly between 1928 and 1931, the trilemma boiled down to a dilemma. Exchange rate stability and a peg to gold emerged as superior policy goals (Sardà, 1936; Vandellós, 1936; Velarde, 1968; Martín-Aceña, 1984). Because of that, Spain was not exempt from other countries' limitations in dealing with the 1931 financial crisis, as policymakers faced very similar constraints to countries on gold. My argument is supported by new archival evidence that combines bank-level data on bank borrowing from the the BdE's discount window during the critical months of 1931 with balance sheet data also at the bank level. This allows me to track major changes in the BdE's lending operations at a daily frequency and couple them with bank balance sheets in order to assess the evolution of liquidity and bank portfolios during and after the crisis.

The main finding of the paper is that when a large number of depositors panicked following the proclamation Second Spanish Republic in April 1931 and banks started losing deposits, Spanish monetary authorities fell prey to the vicious cycle of a "third-generation" currency crisis. ${ }^{1}$ In this context, LLR interventions in emerging economies tend to be less effective than in core, developed economies, because monetary authorities are unable to accommodate the high demand for liquidity denominated in domestic currency without severely affecting the exchange rate and contributing to the ongoing reversal in capital flows (Calvo, 2006). Similar to what Germany, Austria or Hungary suffered also in 1931, the combination of bank and currency problems aggravated the crisis and reduced policymakers' room to act (James, 1984; Schnabel, 2004; Temin, 2008; Schubert, 1991; Macher, 2018). In this sense, the Spanish experience is not dissimilar from the general experience in debtor countries during the Great Depression, as the threat of capital flight put monetary authorities between a rock and a hard place (Wolf, 2008). Comparing bank deposit losses and the liquidity assistance provided by the BdE, I show that because of the limitations outlined above, monetary authorities fell short of providing banks with sufficient liquidity assistance. This limitation was especially binding when banks suffered the sharpest liquidity shocks in April and May. As a result, despite demand for credit 
continued to exist, banks that were affected by the bank run contracted lending. Banks that were unaffected continued to lend. I also find that banks that obtained more liquidity assistance from the BdE called back less loans, suggesting that, within its limits, the intervention of the BdE worked in the right direction.

The Spanish experience in 1931 provides an interesting case study of the effects of a bank run that had little to do with depositors' perception of bank fundamentals, despite there were important vulnerabilities in the banking sector. Consistent with contemporary narrative accounts, I find that the only predictors of bank-level deposit losses during the bank run that started in April 1931 are specific political and social developments and an increase in hoarding, but not observable bank fundamentals. In a similar vein to what Bernanke (1983) and Anari, Kolari, and Mason (2005) described for the banking panics in the United States during the Great Depression, my results show that even once hoarded cash returned to banks after the panic subdued, it was parked into safe liquid assets and lending to the non-financial sector did not recover, thus highlighting the persistent effect of sharp liquidity shocks among affected banks. However, in contrast to the case of the United States, Germany or Austria, where bank failures were a central feature of the 1930s banking crises, my findings show that even in the absence of widespread or large bank failures, the contraction in bank loans was sharp and permanent. ${ }^{2}$

The rest of the paper is organized as follows. Section II reviews the literature on the Great Depression in Spain and relates it to the one on twin crises. Section III explains the limits to the LLR intervention. Section IV describes the new data sources used and Section V conducts an empirical approach to the determinants of the 1931 bank run as well as to the consequences of the limitations faced by monetary authorities. Section VI concludes.

\section{The Gold Standard and the Great Depression in Spain}

\subsection{Revisiting tradition}

Conventional accounts of the Great Depression argue that Spain managed to escape it. As the only country that operated an inconvertible currency-the peseta-Spain had two advantages over countries on the Gold Standard. First, thanks to the depreciation of the peseta that started in 1928 Spain avoided the deflationary pressures that plagued most countries (Choudhri and Kochin, 1980; Temin, 1993). Second, when a bank run ensued in 
1931, the BdE would have been able to lend freely at banks' demand as it was not subject to the strictures of a gold-convertible currency (Tortella and Palafox, 1984; Reinhart and Rogoff, 2009). In addition, since Spain did not experience widespread bank failures during the 1930s, it is commonly coded as not having suffered a banking crisis in 1931 (Bernanke and James, 1991; Grossman, 1994).

\section{FIGURE 1 ABOUT HERE}

\section{FIGURE 2 ABOUT HERE}

This section provides contrasting evidence. ${ }^{3}$ Between 1931 and 1934, the Spanish economy accumulated a GDP loss of $13 \%$, defined as the deviation from the pre-crisis growth trend (Betrán, Martín-Aceña, and Pons, 2012). Figure 1 shows that between 1929 and 1933, Spain fared much worse than countries that devalued in the autumn of 1931 (UK, Denmark, Norway, Sweden) and than countries that remained on gold (e.g. Belgium, Italy or Switzerland). In fact, Eichengreen and Mitchener (2003) find a very sharp contraction in their credit composite indicator for Spain, which is comparable to the one experienced by Germany or the United States. More recent and higher frequency estimates of monthly economic activity provided by Albers (2018) reveal a similar picture: the recession in Spain was severe, and as long-lasting as in many countries on gold. Other measures of economic activity tell exactly the same story; private investment and bank lending collapsed in 1931 (Figure 2).

The country was also affected by the reversal in international capital flows that took place during the late 1920s and early 1930s (Accominotti and Eichengreen, 2016; Betrán and Pons, 2018). As a result, the peseta started depreciating rapidly from 1928 (Figure 3). The depreciation of the peseta certainly explains higher comparative inflation rates during the late 1920s vis-à-vis countries on gold, as Choudhri and Kochin (1980) argued. But when deflation became a worldwide concern in the early 1930s, Spain suffered a drastic appreciation of the real exchange rate versus Sterling and the US Dollar (Figure 4). By mid-1932, Spanish authorities pegged the peseta to the French Franc, overvaluing the exchange rate and importing deflation (Martín-Aceña, 1984). Given the international depression, external demand did not contribute to avoid deflationary pressures. Exports collapsed by 
43\% between 1931 and 1935, and data on prices confirms this: the GDP deflator points to a drop in the aggregate price level in 1932 and 1933, mainly driven by the collapse of import and export prices (Prados de la Escosura, 2003). The CPI fell by $3.1 \%$ during 1931-35, while WPI fell by $8.2 \%$ during the same period (Instituto Nacional de Estadística, 1934; Maluquer de Motes, 2013). This is not surprising for a country in which $80 \%$ of exports were commodities (Tena, 2005). Moreover, real interest rates increased during the early 1930s, despite the BdE cut the Discount and Lombard rates from 1932 (Comín, 2012).

FIGURE 3 ABOUT HERE

FIGURE 4 ABOUT HERE

\subsection{Gold Standard mentalité and twin crises}

Spanish policymakers and the public in general hardly appreciated any potential benefits stemming from a falling peseta. Several Ministers of Finance resigned as a consequence of the depreciation that took place between 1928 and 1931, which contributed to reinforce the link between the evolution of the peseta and political instability. ${ }^{4}$ Currency appreciation was regarded as a sign of prowess, while depreciation was politically unacceptable. Despite gold-inconvertibility of the peseta, Spanish policymakers were bounded by the same intellectual framework of the time, the so-called gold-standard mentalité (Eichengreen and Temin, 1997; Mouré, 2002; Straumann, 2010). This is not surprising; the literature on emerging markets and exchange rate regimes shows that policymakers tend to be reluctant to either allow their exchange rate to float freely (Calvo and Reinhart, 2001, 2002), or to reveal the true nature of their policies, highlighting the difference between de jure and de facto exchange rate regimes (Levy-Yeyati and Sturzenegger, 2005; Urban, 2009). Spain never abandoned the aspiration of a strong, fixed exchange rate and a gold-convertible currency, and enacted policies that pursued these goals.

Banking crises in emerging markets rarely happen in complete isolation. Instead they frequently take place along mounting deterioration in the balance of payments (Bordo and Meissner, 2006; Reinhart and Rogoff, 2009). This explains why the provision of emergency liquidity by the central bank can be severely limited. The collapse of the exchange rate 
feeds back into the already weak banking sector, which is commonly affected by currency mismatches (Bordo, 2006). In this framework, so-called "third generation currency crisis", currency depreciation is reinforced by growing currency mismatches in banks and firms' balance sheets (Krugman, 1999; Chang and Velasco, 2000). In this context, the provision of emergency liquidity to the banking sector might have strong drawbacks. Holders of domestic currency will then expect further depreciation as monetary authorities will have to expand the monetary base to provide liquidity assistance to ailing banks, among other things, to meet depositors' demands of repayment. Policymakers find their hands tied, and eventually have to resort to capital controls and international assistance, a problem that core, developed economies do not necessarily experience (Calvo, 2006; Rey, 2015).

It is usually difficult to identify the initial shock that triggers the vicious cycle described above (Kaminsky and Reinhart, 1999; Schnabel, 2004). The Spanish experience provides an interesting case study because it allows for the identification of a clear exogenous trigger for the bank run: the unexpected results of the April 1931 local elections. Almost overnight, Spain changed from a Monarchy that had sympathized and co-existed with authoritarianism to a democratic Republic. Despite the peseta had been falling since 1928, banks had continued to receive deposits until March 1931 (Figure 6). By then, however, currency mismatches in the banking sector had increased substantially (Figure 7). In this context, the bank run was the spark that put in motion the "third-generation" dynamics described above.

\section{FIGURE 6 ABOUT HERE}

\section{FIGURE 7 ABOUT HERE}

The fact that the peseta was not convertible to gold did not imply unlimited room for LLR interventions. The conventional account described above implicitly neglects the fact that the BdE operated a currency that could not be converted to gold, but not a

completely fiat currency. Taking the two things as synonyms is misleading. ${ }^{5}$ There were limits on how much monetary base could be created, and this depended on the gold-and to a much lesser extent silver-reserve at the BdE (Martín-Aceña, Martínez-Ruiz, and Nogués-Marco, 2013). In fact, when the bank run started in April 1931, there was very 
little room to expand the fiduciary issue to support ailing banks. Interestingly, Spain did not lack international reserves. The BdE held the world's fourth largest gold reserve at the time, only after the US, Britain and France. However, already from 1928, all governments failed to persuade the BdE to use gold sales to stabilize the exchange rate, as all parties involved disagreed on the specific stabilization policies and their costs. Hence, on top of balance of payments and monetary constraints, institutional design also played a role in limiting the policy reaction in 1931. This explains why during the crisis, temporary stabilization of the exchange through gold sales was never a feasible option.

\section{The Banco de España as a constrained lender of last resort}

\subsection{The stabilization of the peseta and "original sin"}

Incumbent politicians and the public in general decried the fall of the peseta. The appreciation that took place in 1926-27 had pushed dictator Miguel Primo de Rivera and his Minister of Finance José Calvo-Sotelo, to make exchange rate stability the cornerstone of the regime's economic reputation, going as far as tying exchange rate stability to moral and racial considerations. ${ }^{6}$ This backfired when capital started leaving the country and the peseta began to fall in 1928. The evolution of the exchange rate became the main reason behind the resignation of several Ministries of Finance (including Calvo-Sotelo) and one of the main factors behind the growing discredit and later resignation of Primo de Rivera (Velarde, 1968; Eguidazu, 1979; Ben-Ami, 2012). Interestingly, in 1929, Primo de Rivera himself regretted that "when almost a year ago we saw the peseta around 27 per Sterling, national vanity made us dream for some hours about reaching parity with gold [i.e. the 1868 parity]. The Gold-Peseta! Viva España! That was more a moral success than an economic one...".7 Some years later, in 1933, Calvo-Sotelo claimed that "if in 1927 the Government had intervened-our critics claim-it would have been possible to buy foreign exchange in order to create a large reserve. This is not only an ex-post recommendation but also unfair. Monetary interventionism to stop the appreciation of a currency! No. In 1927, no government would have dared doing that". ${ }^{8}$

Thus, from 1928, the fall of the peseta and the discredit of the Spanish Monarchy and its different executives (the Dictatorship and later the so-called Softatorship) became strongly interlinked. ${ }^{9}$ As a response, in January 1930 the Dictatorship took the last 
attempt to stabilize the peseta: the issuance of gold bonds. The Government issued 350 million pesetas in 10-year gold bonds in the first days of 1930. The goal was to liquidate the Government's accumulated short term foreign exchange debtor positions, which had been growing since 1928, when foreign exchange interventions started and failed repeatedly. ${ }^{10}$ Gold bonds were very attractive: they paid unusually high yields (6\%), were made eligible as collateral at the discount window of the BdE at a rate specially set for these bonds (4\%) and carried taxation exemptions. Subscribers of the bonds could acquire them either with gold (coins or bullion, domestic or foreign) or with foreign, gold-convertible currencies. Coupons were to be paid quarterly in gold-pesetas, which were defined at the parity of 1868 , of 25.20 pesetas per Sterling or 5.18 pesetas per US Dollar. They could be serviced in foreign gold coins and in bills denominated in currencies that were convertible to gold. In short, gold bonds were redeemable in foreign exchange at the 1868 parity. ${ }^{11}$ Despite previous failed attempts to stabilize the peseta, demand for gold bonds was very strong. ${ }^{12}$ Bonds were bought mainly by Spanish and foreign banks, while the BdE ended up not holding any. ${ }^{13}$ In practice, in trying to stop the fall of the peseta, the Dictatorship transferred currency and maturity mismatches from its balance sheet to the banking sector's, thus planting the seeds for a twin crisis, were banks to suffer a sharp liquidity shock. ${ }^{14}$ Strong demand for gold bonds was interpreted as a signal of solid confidence in the stabilization of the peseta, but the latter continued to fall during 1930, as current account deficits mounted and capital continued to leave the country (Figure 3). By the time gold bonds were issued, the peseta traded at $70 \%$ of its 1868 parity; just before the proclamation of the Republic in April 1931, it traded at 54\%; by September 1931, just before Britain left gold, it traded at 45\% (Figure 3). The continued depreciation of the peseta made honoring the bonds increasingly expensive for the Government. Even more so as the collapse of international trade caused a fall in foreign exchange revenue at the customs, making it even more costly to service coupon payments in gold-convertible currencies. $^{15}$

\section{FIGURE 5 ABOUT HERE}

Spanish banks didn't hold any gold themselves, and they held almost no foreign exchange in cash, so they borrowed abroad. ${ }^{16}$ They did so by embarking in short-term forward contracts in London (so-called dobles in Spain) by which they sold spot pesetas against Sterling, and repurchased them at a term no longer than three months. As 
long as the peseta did not depreciate rapidly or if foreign exchange markets trusted the stabilization plans of the Government, banks were able to rollover these operations, especially because their access to the discount window of the BdE was not quantitatively limited before April 1931. If the peseta continued to fall, this would cause severe pressure to their balance sheets by increasing their currency mismatches even more, and would leave them unable to repay their lenders in gold or "hard currency". To do so, they might also have to access the discount window of the BdE to obtain pesetas and buy Sterling, thus contributing to existing pressure on the exchange rate. Therefore, by the time the banking crisis started in April 1931, banks were in a very fragile position, as they had rapidly accumulated currency mismatches after several years of lowering their exposure to exchange rate volatility (Figure 7).

The BdE had not subscribed to any of the government gold-bonds, and therefore was reasonably isolated from the direct effects from the fall of the peseta. Moreover, it valued its gold reserves at the parity of 1868 , so its profits were protected from fluctuations in the nominal exchange rate. However, when in April banks started losing deposits and turned to the discount window, the BdE faced a binding trade-off between liquidity provision and exchange rate stability. Right after the proclamation of the Republic, the BdE acknowledged that: ${ }^{17}$

"(...) banks have faced deposit withdrawals that forced them to resort to us, to be able to comply with their clients' demands, by rediscounting bills and using their credit accounts. This has caused circulation to increase (...) and despite the fact that we have enough reserves to allow for larger increases in money circulation and will attend to the petitions that we are required to attend to, the assistance that is provided to private banks must be consistent with their healthy policy and the current circumstances, with the final aim of avoiding an excessive increase in the volume of circulation, and thus affecting the external value of the currency and the price level (...)"

While ready to help, the BdE was constrained. It also feared losing gold. Officially, its gold reserve was only at risk if the BdE agreed to use it to join the Government in a stabilization plan that happened to go wrong, something the former had resisted since 1928. Only then, the Government could ask the BdE to cover $50 \%$ of the costs of the intervention with its own gold reserve. ${ }^{18}$ 
In October 1930, amid the unstoppable fall of the peseta and unable to get the BdE involved in gold sales to intervene in foreign exchange markets, the Government had sent a delegation of the BdE to meet with representatives of the Bank for International Settlements (BIS) in Paris (Martín-Aceña, 2006). The goal was to ask for a credit in Sterling for the final stabilization of the currency. Negotiations continued in London, where Montagu Norman, the Governor of the Bank of England, argued that Spain should use the BdE's gold reserve to stabilize the peseta before asking for external assistance. In fact, Norman believed that news about the BdE mobilizing its gold would suffice to stop the depreciation. ${ }^{19}$ Norman's hard opposition to a line of credit failed to understand the high political sensitivity of gold-related issues in Spain (Toniolo and Clement, 2005); the BdE abhorred the idea of mobilizing gold or using it as collateral for international credits. ${ }^{20}$ Norman's stance is perhaps better explained by his fears of the potential spillovers of an excessive intervention of the BIS in Spanish affairs: ${ }^{21}$ "the responsibility over a long period of stabilization is a domestic and political question and, judging from past experiences, great difficulties are liable to arise and mistakes are liable to be made, which cannot be assumed by the BIS or anybody in that position".

Finally, a solution that satisfied both Norman and Spanish monetary authorities was found. The BdE agreed to ship gold to London as collateral for the BIS stabilization credit (Figure 5b). In turn, the BIS acceded to extend the loan, but only after a stabilization plan for the peseta was put on paper by Federico Carlos Bas, then Governor of the BdE. The plan, which had been actually drafted by BIS agent Michel Mitzakis, stipulated that: "Spain would reform its monetary system by adopting the gold bullion standard, after a transitory phase on the gold exchange standard, at a somehow devalued parity relative to the prewar period". ${ }^{22}$ On 29 December, the BIS lent $£ 1.5$ million to the BdE for a duration of three months, to be fully reimbursed, principal and interest, in one single payment at maturity. ${ }^{23}$ The BIS charged $2.5 \%$ interest and a $0.125 \%$ commission, and the loan was fully collateralized by $£ 1$ million in gold bars and $£ 0.5$ million in gold coins, deposited at the Bank of England in the name of the BIS. The credit was doubled to £3 million after the three initial months, on 29 March 1931. In addition to the BIS credit, the Government had also approached foreign banks to ask for stabilization loans. This materialized on 26 March 1931, when J.P.Morgan, the Banque de Paris et des Pays Bas and Mendelsshon \& Co. opened credit accounts to the BdE with the guarantee of the Government, amounting to 60 millions US Dollars, and to be repaid in 18 months and at a rate of $1.0 \%$ above the 
discount rate of the Federal Reserve Bank of New York. ${ }^{24}$ After months of negotiations and a falling peseta, the outcome of the agreement with the BIS and foreign banks and Spain's commitment to join gold, was well received in foreign exchange markets, causing the peseta to appreciate in the very days before the Republic was proclaimed (Figure 8).

\section{FIGURE 8 ABOUT HERE}

The appreciation trend ended when the Republic was proclaimed on 14 April 1931 (Figure 8). Just as its predecessors, the provisional Republican Government thought that domestic and foreign speculation against the peseta was the cause of its unstoppable depreciation, and wanted to identify its ultimate source before making any clear public statement about a new stabilization plan involving a specific peg (Martín-Aceña, 1984). The main consequence of this was a sudden stop in foreign stabilization loans; international lenders canceled the credits they had opened less than a month before. ${ }^{25}$ Foreign creditors claimed that stabilization loans were not supposed to be used for ad hoc interventions that deviated from the plan Spain had committed to, so the provisional Government was no longer entitled to the funds. From the very onset of the crisis, Spanish monetary authorities had very little room to defend the peseta in foreign exchange markets.

\subsection{Capital outflows and fiduciary issuing limits}

The second important limitation faced by Spanish monetary authorities came from the quantitative cap on how much fiduciary currency could be created. The fiduciary limit (the amount of notes that were not covered by the metallic reserve) could be raised only after the approval of the Government. ${ }^{26}$ This implied that just as in gold standard countries, room for LLR was ultimately limited by the metallic cover. Figure 9 plots the evolution of notes in circulation as a percentage of the legal maximum as well as daily borrowing from the BdE. On 14 April 1931, the day the Republic was proclaimed, fiduciary notes in circulation were already at $95 \%$ of their legal maximum. One day later, banks approached

the BdE to ask for an increase in the note issuing limit. ${ }^{27}$ The vice governor of the BdE, Mr. Pedro Pan argued that there were enough notes in circulation and that "maybe after some days, things will ease". This optimism contrasted with the situation banks were facing and, after they insisted on the urgency of the situation, Mr. Pan accepted to ask 
for approval from the Government. ${ }^{28}$ A formal petition was sent to the Government on 18 April 1931, when the BdE had already exhausted its room to lend (Figure 9). The provisional Minister of Finance of the Republic, Indalecio Prieto, replied that the increase would not be above 200 million pesetas, over the existing limit of 5000 million, a tiny $4 \%$. This was also considered enough by the BdE, but banks claimed it was insufficient, and urged the Minister and the BdE to understand that the demands were not from banks themselves, but were the result of clients' liquidation of their deposits. ${ }^{29}$ The Government did not move until 5 May. On that day, banks lamented that "the Minister of Finance, after resisting since 18 April without authorizing the increase in note circulation, finally decided to increase it." 30 Two days later, on 7 May, the increase became effective, but given its small size, the limit was quickly reached again. Right after the first change in the note cover ratio ( 7 May), which caused the legal limit to increase by 200 million pesetas, notes in circulation started to increase fast as banks continued to face deposit withdrawals. Notes reached the new legal limit of 5200 million pesetas, pushing for further action.

\section{FIGURE 9 ABOUT HERE}

\section{FIGURE 10 ABOUT HERE}

The provisional Government was extremely concerned with capital flight, and saw the latter as the main link between banking and currency problems. Increasing the fiduciary issuing limit again would imply that banks would receive more liquidity, either to keep rolling over their forward positions in pesetas or to pay back depositors, who would also probably convert their pesetas into "hard currency". ${ }^{31}$ This explains why the second, more ambitious increase in the fiduciary note limit, could only come after capital controls were introduced, on 29 May. ${ }^{32}$ On this day, the issuing limit was raised to 6000 million pesetas-the legal maximum and a $20 \%$ increase from the beginning of the crisis-at the same time that capital controls were introduced through a Decree that limited and banned operations in foreign exchange. ${ }^{33}$ As Figure 9 shows, right after the second change in the cover ratio, discount window borrowing surged.

Rather than a remedy, the increase in the fiduciary issue was considered a policy failure. The day before signing the Decree that allowed for the increase in fiduciary issue, 
the Minister of Finance, Mr. Prieto, presented his resignation to the President of the Republic, Niceto Alcalá Zamora, who refused to accept it. Mr. Prieto considered that the increase in the fiduciary issue limit was evidence of his failure to deal with the crisis (Cabezas, 2005). The next day, when the increase in note issuing was authorized, he then presented his resignation to the Council of Ministries, but he was also forced to remain in charge of financial affairs (Velarde, 1983). Moreover, the Government faced the additional problem that increasing the fiduciary limit would be interpreted by the public as a signal that the banking crisis was more severe than initially thought. As a result, it took one month and a half between the moment in which banks had started to suffer deposit withdrawals and the provisional Government authorized for a second, large increase in the fiduciary issuing limit. Interestingly, the Bank of England faced the same problem in the last days of July 1931, but it was allowed to expand the fiduciary issue as early as on 1 August (Accominotti, 2012). That said, the developments in foreign exchange markets once the increase in the fiduciary note issuing limit was authorized in the last days of May, provide some rationale for the delay in allowing the BdE to lend freely. Daily quotations of spot and forward pesetas in London are plotted in Figure 10. The increase in the issuing limit became effective on 29 May, a Friday. Next Monday, the peseta started trading at a heavy discount, and it fell by $14 \%$ against Sterling. Far from reassuring foreign exchange markets, the policy reaction needed to deal with banks' liquidity shock was in direct conflict with the stabilization of the exchange rate. Right after the Government increased the note issuing limit and introduced capital controls, the Financial Times read: ${ }^{34}$

\begin{abstract}
"Spanish pesetas continued their record-breaking career (...). The increase in the fiduciary issue and the flight of capital are the contributory factors leading to lack of confidence. (...) the swelling of the fiduciary note issue to its legal maximum is an indicator of broken-down confidence, and this must be accentuated by the confession that the government feels bound to authorize further issues, that is, inflation."
\end{abstract}

If the provisional Government feared the collapse of the peseta, what tipped the balance and pushed it to decide forgoing capital mobility and allowing the BdE to increase the fiduciary issue? Contemporary accounts show that it was only when the real economy started to suffer the consequences of the monetary shock that the Government was pushed to make a decision. Just before the note issuing limit was raised and capital controls were introduced, La Epoca reported that: ${ }^{35}$ 
"Talks are being held about increasing the note issuing limit as firms are suffocating, due to the restriction of credit from banks."

The restriction of credit was especially hard in the real estate industry, but it was not the only one affected. ${ }^{36}$ Members of different industries met with Mr. Prieto, who acknowledged the meeting as a reason behind the expansion of the fiduciary issuing limit: ${ }^{37}$

"I received the visit of members of industry, trade and real estate from Madrid, which came to me to explain the truly anxious situation in which they find themselves because of the credit restrictions from banks. Since banks justify the contraction in credit because the Banco de España is restricting rediscount operations, I announce that an increase in note circulation will be authorized. (...) Even though this might not be a pleasant measure, it will contribute to eliminate the current suffocation caused by the restriction in credit."

Interestingly, the Minister passively acknowledged the mistake of having increased the issuing limit only by a small amount earlier in May: ${ }^{38}$

"This afternoon I signed the decree authorizing the increase in fiduciary circulation (...) in order to eliminate workers' anxiety, as they are being fired in large quantities because banks are restricting credit. To avoid having to keep pinching small increases in circulation, I authorized for the maximum increase, six million pesetas."

On the day the issuing limit was raised, La Libertad reported that: ${ }^{39}$

"Before the issuing limit was raised, banks were cutting down lending because they could not rediscount [at the BdE]".

As capital controls became tighter and more effective, pressure on the peseta eased. On 2 June 1931 the Government forced exporters to convert their holdings of foreign currency into pesetas and asked banks to submit a statement with their holdings of gold bonds and foreign currency, which would eventually be centralized and liquidated. ${ }^{40}$ Crucially, it started negotiating a credit with the Banque de France $(\mathrm{BdF})$ in Paris. The BdF would 
replace the BIS, whose credit would be let to expire at maturity at the end of June. News about the negotiations with the BdF caused the peseta to appreciate substantially. ${ }^{41}$ After the insistence of the newly appointed Governor of the BdE, Julio Carabias, the board agreed to ship £6 million in gold to the Banque de France branch in Mont-de-Marsan (the closest branch to the Spanish border), as collateral for an equivalent credit in Sterling. ${ }^{42}$ The loan would be used to nationalize forward contracts in pesetas in London to solve the problem that banks had to service them amid a falling peseta (Martín-Aceña, 1984). Although pressure on the peseta mounted again from mid July (despite an increase in the discount rate) banks currency mismatches eased considerably thanks to the credit obtained from the Banque de France (Figure 7). By the end of August, foreign exchange markets started expecting the peseta to be stabilized at 52 pesetas per Sterling. ${ }^{43}$ Meanwhile, the Government kept trying to get the BdE involved. Having acceded to mobilize gold to the Banque de France, the Government tried to increase the pressure for further uses of the gold reserve, although no more gold was shipped. ${ }^{44}$ Increased pressure from the Government on the Board of the BdE to use its gold reserve changed market expectations about the future of the peseta, as markets interpreted this as a possibility that gold sales to defend the peseta might take place. This somewhat confirmed Montagu Norman's claims that more than moving gold, it was the willingness to do so what would ease pressure on the peseta. ${ }^{45}$ This kick-started an appreciation trend that was reinforced soon enough, when Britain left gold on 21 September 1931 and political stability improved in the second half of October 1931.

\section{Data}

The new dataset used in this paper allows to match the two sides of the market - the central bank and the banking system-during the 1931 crisis. Data on daily lending operations from the BdE to the banking sector is obtained from the Actas de la Comision de Operaciones del Banco de España. The second source of data incorporates the banking system. I collect consolidated bank balance sheets on a quarterly basis from 1922q4 until $1934 \mathrm{q} 4$ from the Boletines del Consejo Superior Bancario (CSB). The total number of banks affiliated to the $C S B$ at the beginning of 1931 was 125 , representing $85 \%$ of the banking sector's total assets and holding $89 \%$ of total deposits. In turn, there were 11 foreign banks and 166 small Spanish banks and bankers that were not affiliated to the CSB, which represented $12 \%$ and $3 \%$ of total assets respectively. That said, data from 
the Actas detailed above contains only the operations that were conducted at the BdE's discount window in Madrid. This implies that I am only able to couple the two sides of the market for 24 banks, while I can use the full sample when data from the BdE is not involved. However, these 24 banks represent around $65 \%$ of the total banking sector assets (Table 7), thus making the sample representative. ${ }^{46}$ To the extent that it was feasible, I solved these data limitations by accessing a number of individual bank archives to gather information on their daily borrowing from the BdE from their ledgers. I could do this for three additional banks that borrowed mostly in the BdE's branch in Barcelona, which increases the geographical variation of the dataset. ${ }^{47}$ Information about variables used in the empirical estimations and about banks is provided in Tables 6 and 7 in the Appendix. I also gather and use qualitative information from the Minutes and Meetings of the Board of the CSB (Actas del Consejo Superior Bancario), the Minutes of the Board of the BdE (Actas del Consejo de Gobierno del Banco de España) and annual reports of different banks. I also use data from an occasional report published in 1935 by the Research Department of the BdE, "Liquidez Bancaria, 1931-1934". Where used, other quantitative or qualitative sources are detailed; these are mostly contemporary accounts from economists, politicians and both the Spanish and international financial press.

\section{The 1931 financial crisis: empirical analysis}

How did banks fare during the critical months of 1931? In order to answer this question, this section conducts two empirical estimations. The first explores the determinants of the bank run at the bank level, in order to show that it had little to do with observable bank fundamentals. The second estimation shows that liquidity shortages at the bank-level predict the evolution of bank lending and provides an analysis of the evolution of bank portfolios after the crisis.

\subsection{Determinants of deposit withdrawals}

Following the boom experienced during the First World War, the Spanish banking sector continued to grow throughout the 1920s. This trend came to an abrupt end between April and September 1931 when, following the Proclamation of the Second Spanish Republic, the banking sector lost $20 \%$ of its retail deposits (Figure 6). To explore the determinants

of deposit losses at the bank level, I conduct four different estimations, which are reported 
in Table 1. Columns 1 to 3 in Table 1 report the results of an OLS regression in which the dependent variable is the negative of percentage change of deposits between 1931q1 and 1931q3, and includes banks that gained deposits during the crisis. Thus, a positive percentage change means losing deposits and vice-versa. Independent variables include a set of measures of bank fundamentals: size, capital ratio, share of public debt and stocks in portfolio, share of long term loans over total loans and currency mismatches. The latter are calculated as the share of deposits denominated in foreign exchange over total loans denominated in pesetas. This aims at measuring the extent to which banks suffered increasing pressure on their liabilities denominated in foreign exchange relative to their revenues in domestic currency. ${ }^{48}$ To control for specific economic conditions at the bank-province level, I include population, population density, the number of bank branches per 1000 inhabitants, bankruptcies prior to the 1931 crisis, work days lost as a result of strikes before the crisis and the change in agricultural value (all at the province level). Finally I also include a set of covariates that aim at capturing political developments: the share of Republican votes in the April local elections and a dummy for banks in provinces facing violent clashes between Republicans and Monarchists in early May. The number of religious congregations per capita is included to control for the confrontation between secularists and the Catholic Church that characterized the period. I also include a dummy for the largest 6 banks, dummies for the main three banking centers, Madrid, Barcelona and Bilbao, and a dummy for banks in provinces of Catalonia apart from Barcelona. Descriptive statistics of the variables included are provided in Table 6 in the Appendix.

None of the variables associated with bank fundamentals or regional economic conditions enter the model significantly. Only in column 3, explanatory variables reach some significance: a bank being in a province where violent clashes were registered in May was more likely to lose deposits, and the same happened for banks in Barcelona and the rest of Catalonia. I further explore the data with a quantile regression (Columns 4 to 8). In this case, I divide the dependent variable in different percentiles (10th, 25th, 50th, 75th and 90th) in order to segment the sample depending on the severity of deposit withdrawals at the bank level. The quantile regression results show a similar picture: observable bank fundamentals do not help predict deposit losses at the bank level. ${ }^{49}$ However, Column 8 shows that for banks suffering the sharpest liquidity shocks through deposit losses, political variables played a role. Both the share of Republican votes and the May episodes described above, enter the regression with large and statistically significant coefficients. ${ }^{50}$ All in all, these results suggest that the bank run that started in April 1931 was not caused 
by any fundamental weakness in the banking sector that could be observed by depositors.

\section{TABLE 1 ABOUT HERE}

While surprising at first, results in Table 1 are consistent with contemporary accounts that claim that depositors converted deposits into cash and hoarded it because of rumors that the Government might expropriate current accounts after conducting an inspection to find out the origins of capital flight and speculation against the peseta (Martín-Aceña, 1984; Velarde, 2015). The inspection did in fact take place in most banks in Madrid but it was conducted without major incidents or opposition from the banking sector and did

not cause any disruption to bank operations. ${ }^{51}$ Finally, the large and positive coefficients associated to the dummy for Barcelona and the rest of Catalonia do capture the contagion episode that took place following the failure of Banco de Cataluña, Banco de Reus and Banco de Tortosa on 7 July 1931 as well as specific political developments that took place in Catalonia right after the proclamation of the Republic (Balcells, 1971).

\subsection{Liquidity assistance and bank lending}

Even if aggregate bank lending contracted by 20\% from April 1931 (Figure 6), not all banks followed this path. Table 2 shows the results of a panel regression with bank and province fixed effects that confirms that it was only banks that suffered a sharp liquidity shock due to deposit withdrawals between 1931q1 and 1931q3 the ones that contracted lending sharply. For this, I regress the log of loans against a dummy for the post-1931q1 period, Post - 1931q1, and the interaction between the latter and a dummy variable called Bankrun. This dummy assigns a value of 1 to banks that suffered a deposit loss between 1931q1 and 1931q3 that was larger than their mean variation in deposits during the three years before the crisis (in percentage). This aims at capturing the average differential impact on bank lending for banks that were affected by the bank run in comparison to those that were not. According to this definition, from the sample of 119 banks, 87 banks suffered a run and 32 did not. The main coefficient of interest is the one associated to the interaction between Bankrun and Post - 1931q1. Across the different specifications in Table 2, it signals that on average, banks that suffered a sharp drop in deposits between April and September 1931, contracted lending around 16 percentage points more 
than those that were unaffected. The coefficients associated with Post - 1931q1 are not significant. Figure 11 provides the same results graphically, in order to show the longer term evolution of bank lending after the shock. By the end of September 1931, unaffected banks' outstanding loans remained at their pre-crisis level. By then, however, affected banks had contracted their loan portfolios around $15 \%$.

\section{TABLE 2 ABOUT HERE}

\section{FIGURE 11 ABOUT HERE}

These results suggest that the main problem some banks faced after April 1931 was a liquidity shortage caused by the bank run; they also rule out the overnight collapse in demand for credit as the main driver of the contraction in bank lending. Therefore, the extent to which banks suffering from the bank run compensated deposit losses with liquidity assistance from the BdE can help understand the evolution of lending during and after the crisis. To assess this, I create a variable that allows for the comparison of the severity of liquidity shocks suffered by individual banks between April and September 1931. The variable aims at capturing the extent to which bank's liquidity needs were satisfied by their access to the discount window of the BdE and by drawing from their own cash reserves. It is defined by:

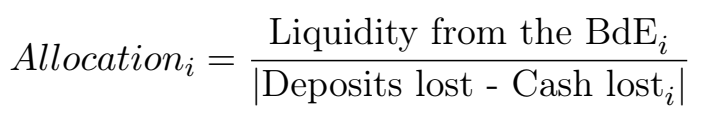

where the term Liquidity from the $B d E_{i}$ is the sum of rediscounts and advances received by bank $i$ between April and September (1931q1-1931q3), while |Deposits lost - Cash lost L $_{i}$ is the absolute value of of deposits lost minus the variation in cash during the same period. An Allocation $_{i}$ value of 1 implies perfect proportionality, as the given bank received enough assistance from the BdE to respond to its clients' deposit withdrawals, taking into account how much cash the bank used to do so before resorting to the BdE. If the variable takes a value lower than 1 (with a lower limit on 0 ) this implies that the representative bank is falling short of liquidity and, everything else constant, will have to 
contract the asset-side of its balance sheet. A bank having an Allocation $_{i}$ value greater than 1 is then receiving excess liquidity. ${ }^{52}$ Looking at banks' daily borrowing from the discount window of the BdE during 1931, it can be seen that liquidity provision was limited until late May, when capital controls were introduced, the fiduciary issuing limit was raised and bank borrowing from the BdE surged (Figure 9). Until the last days of May, banks were effectively competing for limited central bank assistance, and many of them underwent severe liquidity pressure. This is shown in Table 3, which provides the monthly Allocation $i$ value for the largest 6 banks (monthly data is not available for the rest of the sample). The column "W.Average" provides the value of Allocation $i$ weighted by each bank's assets. Until June, Spain's largest banks were under severe liquidity pressure.

\section{TABLE 3 ABOUT HERE}

Can banks' liquidity shortages predict lending after the crisis? To explore this, I run an OLS regression, in which I regress the ratio of loans, assets and different securities

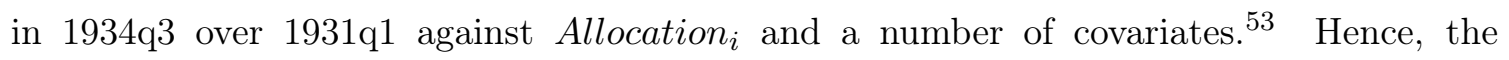
dependent variables capture the evolution of bank portfolios after the crisis compared to their pre-crisis levels. Apart from Allocation $_{i}$, other covariates include the ratio of deposits and capital in 1934q3 over 1931q1, to capture how did bank portfolios react to returning depositors or eventual recapitalizations. I also include bank currency mismatches in order to control for the possibility that banks did use liquidity from the BdE to rollover their forward contracts in Sterling. I also include a dummy for Banco Urquijo de Madrid (BUMA), as this bank was the main recipient of liquidity assistance and is a clear outlier. ${ }^{54}$ Results are reported in Tables 4 and 5.

\section{TABLE 4 ABOUT HERE}

\section{TABLE 5 ABOUT HERE}

Results in Columns 1 to 4 in Table 4 show that banks that received more liquidity assistance during the crisis maintained their loan portfolio afterwards (Figure 12). Even after controlling for how fast banks recovered depositors' hoarded cash after the panic had 
subsided, for recapitalization, and for their exposure to currency mismatches, Allocation remains the main explanatory variable. ${ }^{55}$ The fact that currency mismatches do not enter the regression significantly makes sense because from June, the Government nationalized all banks' foreign exchange liabilities (Figure 7). An interpretation of the average effectiveness of the LLR intervention can be obtained from the coefficient associated to Allocation $i$ in column 5 in Table 4 . This implies that, holding everything else constant, the average bank with an Allocation $_{i}$ value of 1.0, kept its lending portfolio at $43 \%$ of the pre-crisis level. This suggests that, despite political developments, the LLR intervention worked in the right direction: banks used LLR liquidity to keep lending afloat.

\section{FIGURE 12 ABOUT HERE}

Interestingly, when cash hoarding ceased and banks started recovering deposits from September onwards (variable Deposits, Columns 1 to 4 in Table 4), these were not used to extend new loans. Similar to what Bernanke (1983) found for the case of the United States, the liquidation of loans that could not be prevented by the provision of liquidity assistance from the BdE was permanent and instrumental for the deepening of the recession. Columns 5 to 8 in Table 4 confirm this. Here the dependent variable is the ratio of bank assets in 1934q3 over 1931q1. In this case the evolution of bank deposits becomes very significant. This shows, unsurprisingly, that banks that regained depositors' confidence faster also grew back faster. However, if recovered deposits were not lent, how did banks employ them? Columns 1 and 2 in Table 5 show that when banks regained deposits they invested them almost entirely in securities, not in creating new loans. ${ }^{56}$ In particular, Columns 3 to 9 in Table 5 show that returning deposits were mostly invested in public debt and 3-month bills of exchange, while banks' purchase of private bonds and stock remained depressed.

\section{Conclusion}

The findings of this paper provide a reinterpretation of the links between the Gold Standard and banking crises during the Great Depression. So far, Spain has been used as the example of a country that escaped the Depression because its currency was not convertible to gold. Evidence presented here contrasts with this account. After booming growth in the late 1920s, Spain experienced a severe economic contraction following the 
1931 crisis, to which the collapse in bank lending was a major driving force. While political instability and uncertainty did undoubtedly play a role, I find that when the banking system experienced strong liquidity pressure in 1931, monetary authorities were severely constrained, and this limited the effectiveness of their intervention. Trapped in a dilemma between liquidity provision and capital mobility, the BdE could only lend freely when capital mobility was forgone and negotiations started for a stabilization loan with international lenders. As a result, banks suffered severe liquidity pressure and restricted credit supply. The Spanish case suggests that monetary authorities' room to deal with banking crises during the Great Depression was not necessarily determined by the de jure binary contingency of being in or out of gold, but also by comparative levels of financial and institutional development. Despite the peseta was not convertible to gold, Spanish monetary authorities also found their hands (and minds) trapped in golden fetters. 


\section{Figures and tables}

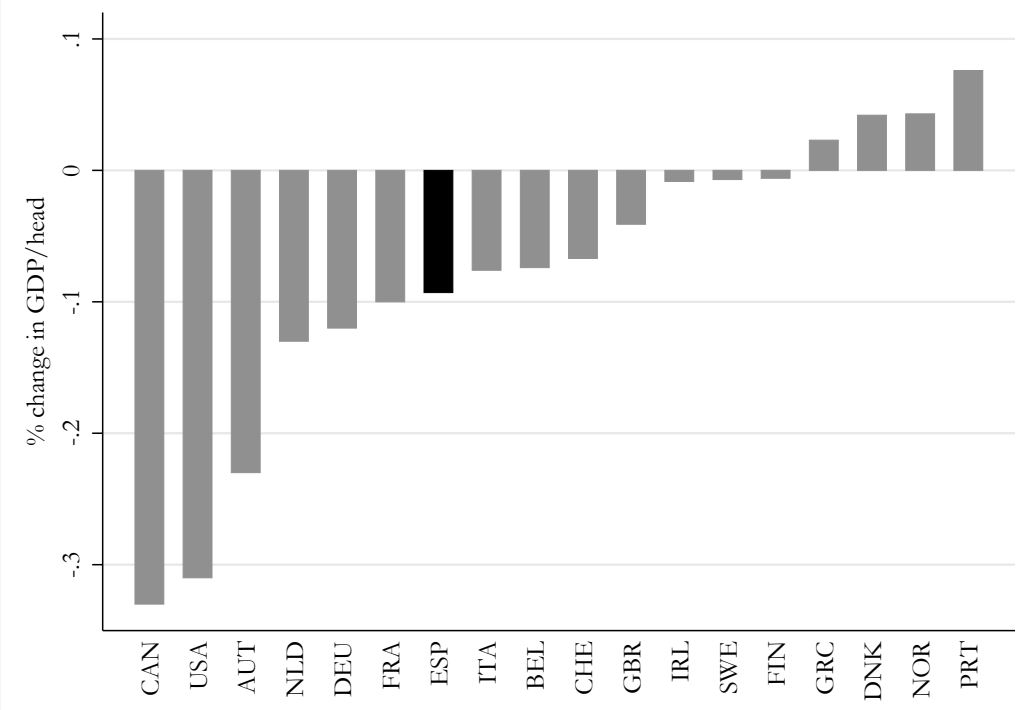

Figure 1: GDP per capita, 1929-1933

Source: Bolt and Van Zanden (2013). 


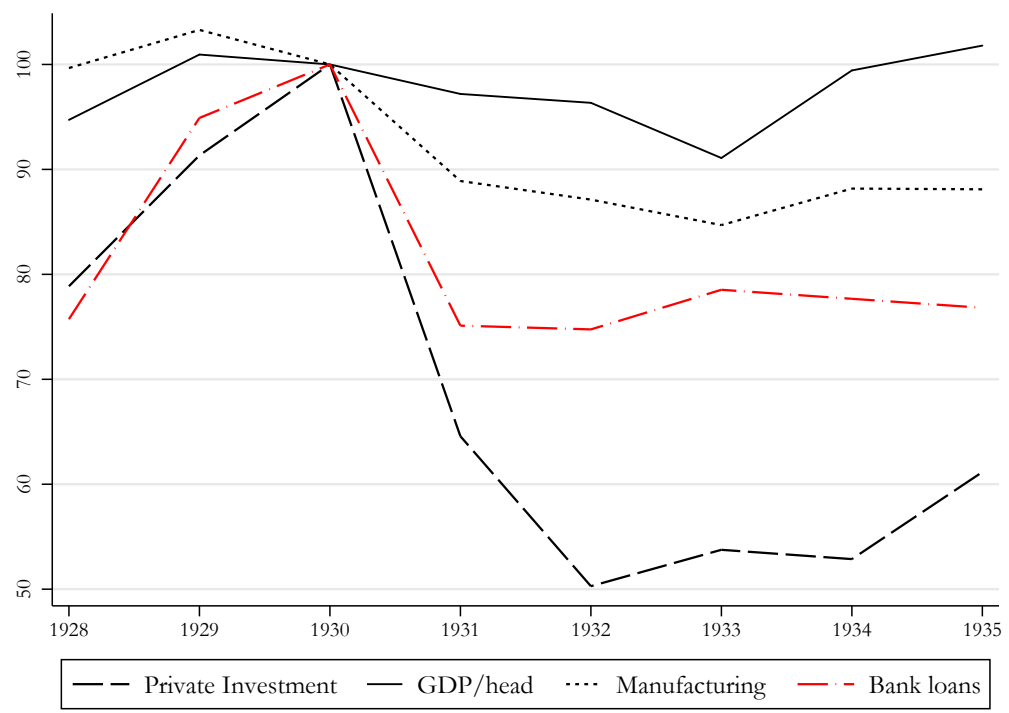

Figure 2: Economic activity $(1930=100)$

Source: Prados de la Escosura (2003) for GDP and its components, Boletines del Consejo Superior Bancario for bank lending. 


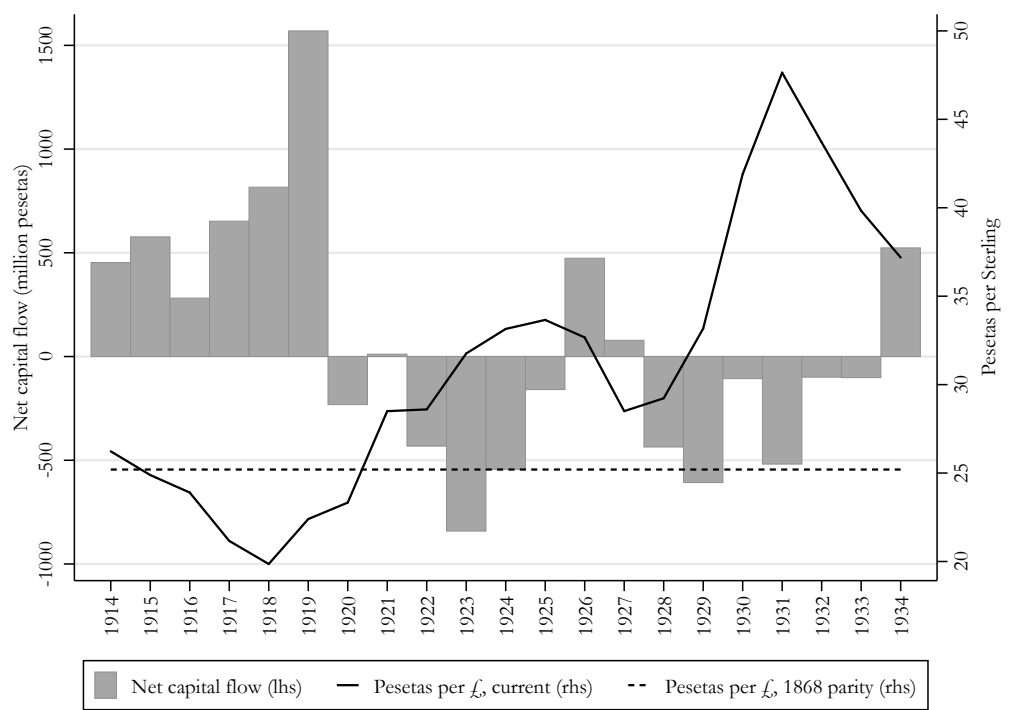

Figure 3: Capital flows and exchange rate, 1915-34

Note: million pesetas. A positive amount represents net capital inflows. Capital flows are estimated by adding the current account balance to the changes in gold reserves. Source: own calculations using Betrán and Pons (2018) and Martínez Mendez (2005).

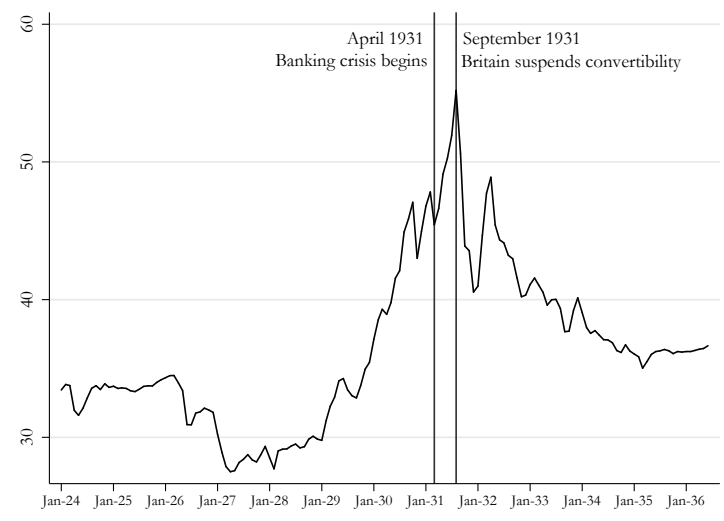

(a) Pesetas per Sterling

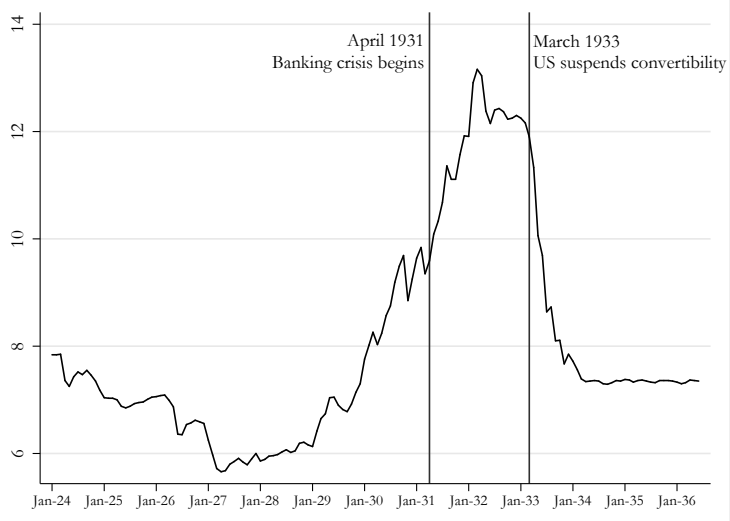

(b) Pesetas per US Dollar

Figure 4: Evolution of the peseta exchange rate (1924-1936)

Source: Martínez Mendez (1990). 


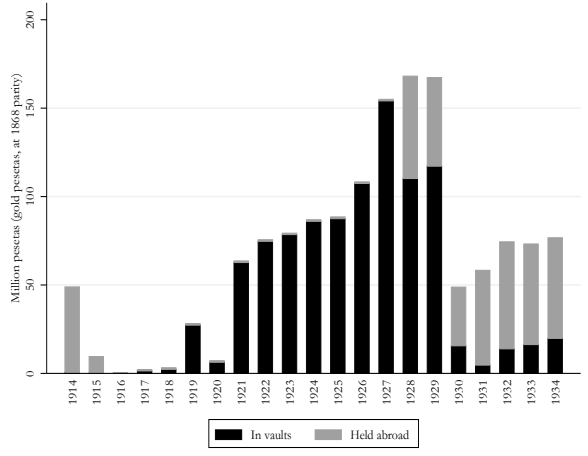

(a) Government

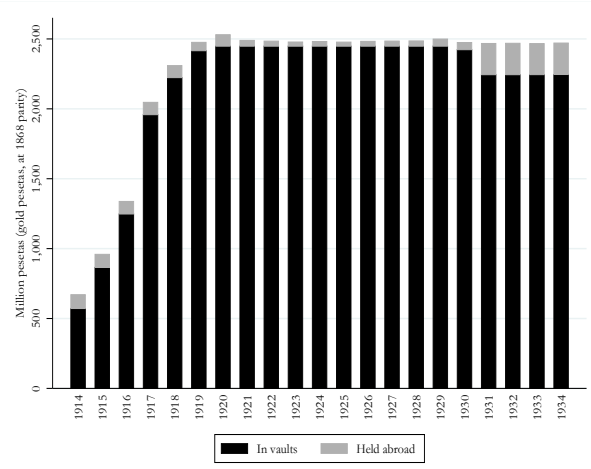

(b) Banco de España (BdE)

Figure 5: Gold reserves, Government and Banco de España (1913-1934)

Note: million gold pesetas (i.e. valued at the 1868 parity of 25.2 Pesetas per Sterling). Source: Martínez Mendez (2005).

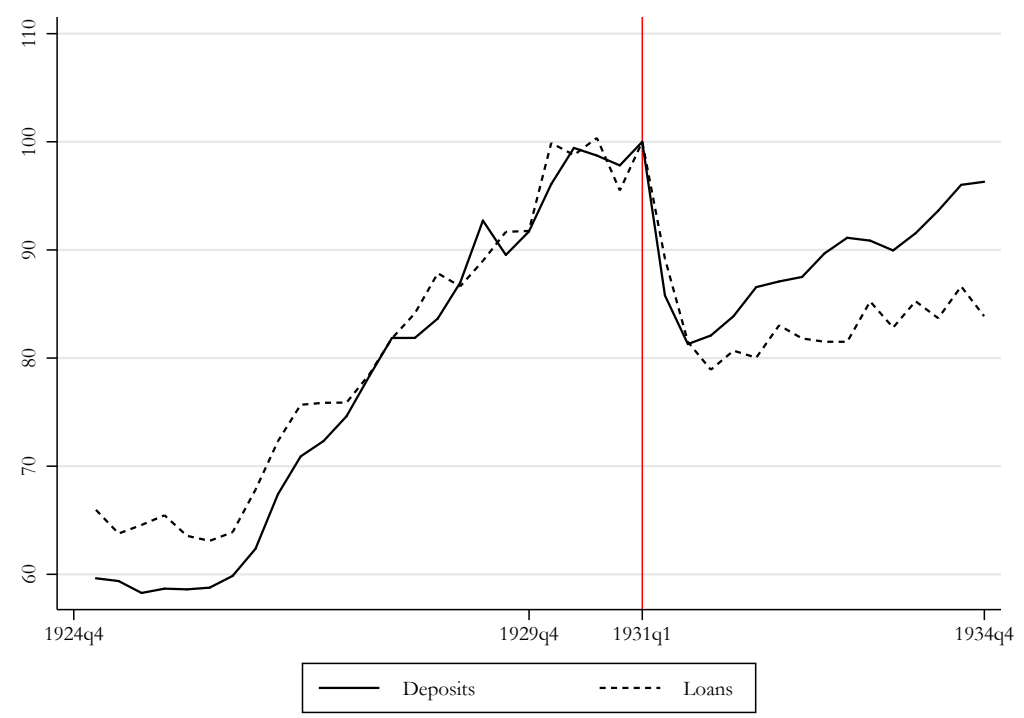

Figure 6: Evolution of total deposits and loans (1931q1=100) Note: deposits and loans in pesetas. Source: Boletines del Consejo Superior Bancario. 


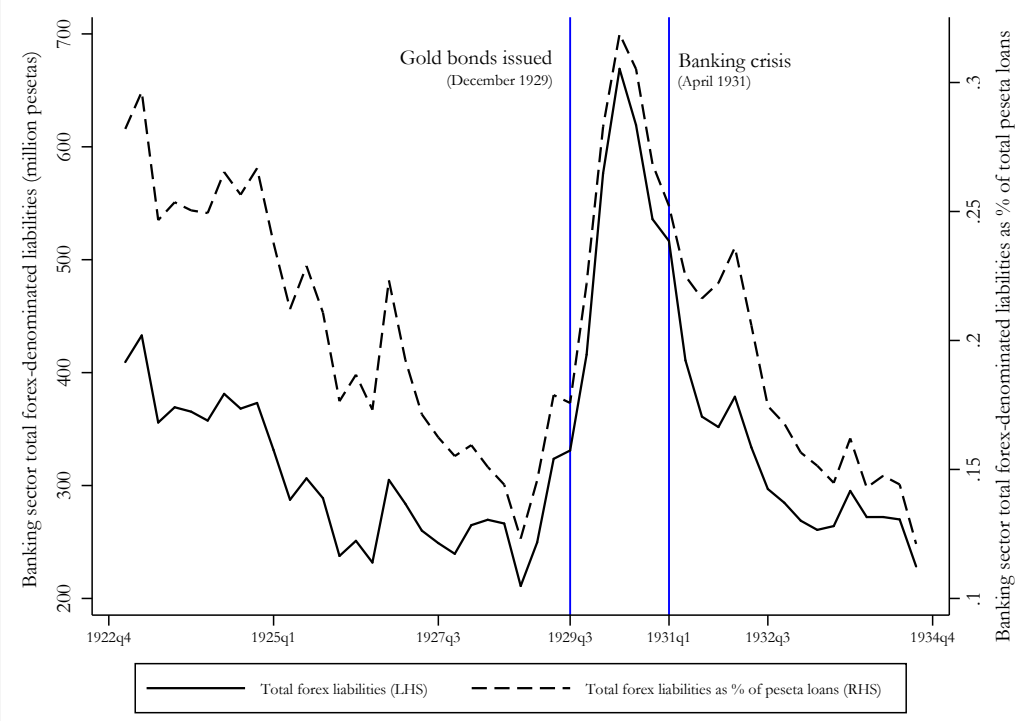

Figure 7: Currency mismatches in the banking system Source: Boletines del Consejo Superior Bancario.

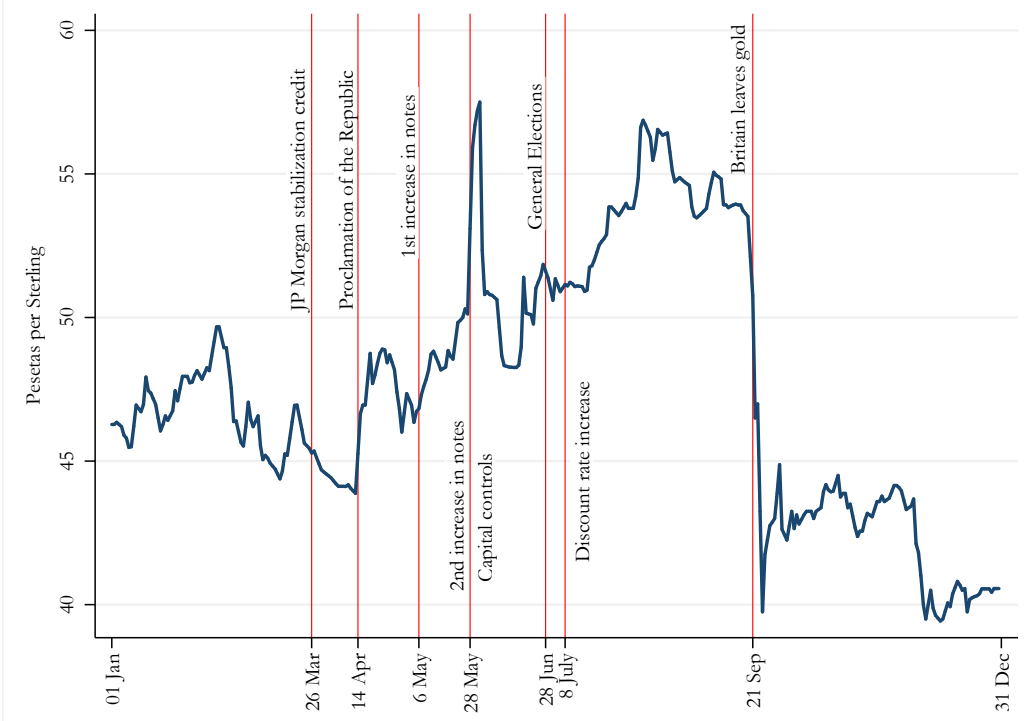

Figure 8: Spot exchange rate of the peseta in London (daily) Source: Financial Times Historical Archive. 


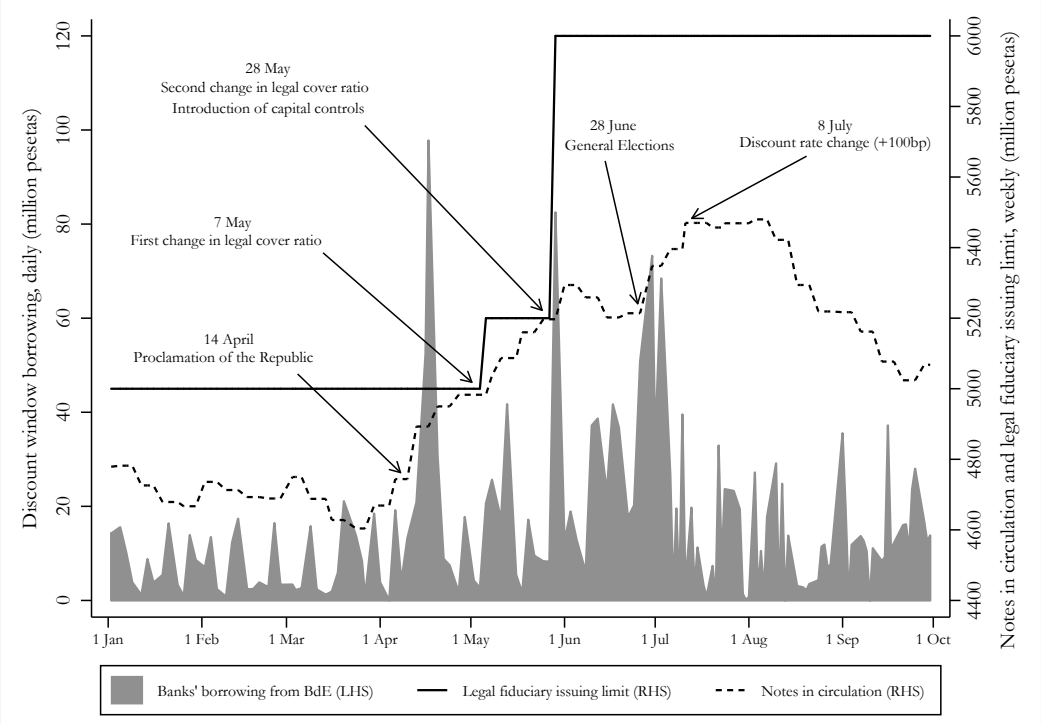

Figure 9: Banks' borrowing from BdE, notes in circulation and legal fiduciary issuing limit (January 1931-September 1931)

Source: Actas de la Comisión de Operaciones del Banco de España for daily discount window lending and Martínez Mendez (2005) for weekly notes issued. 


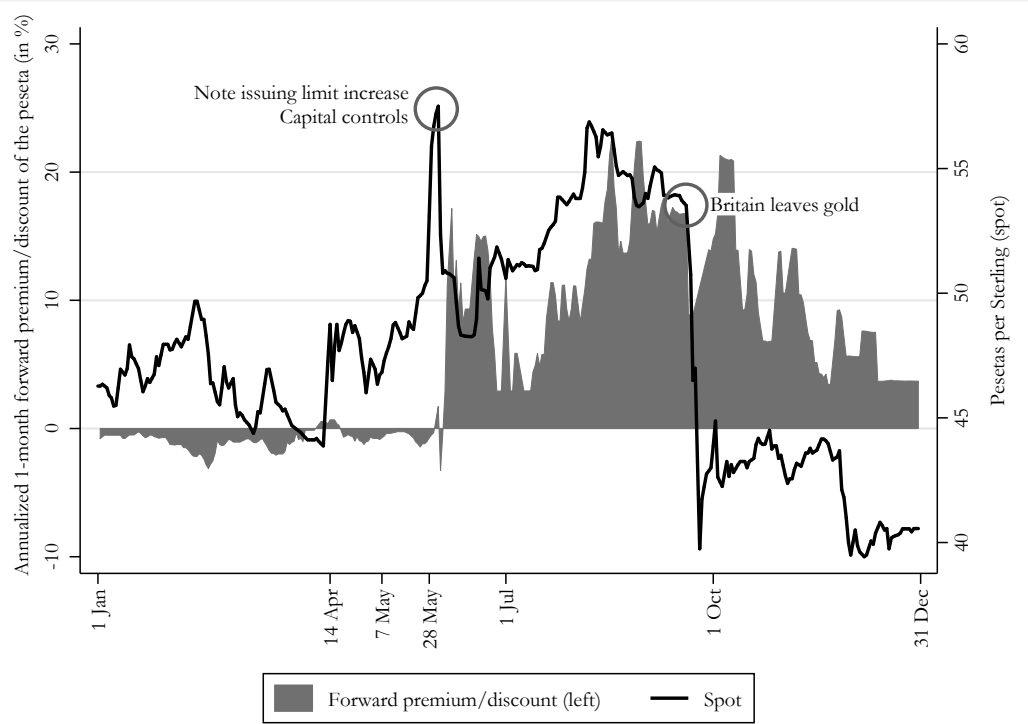

Figure 10: Spot exchange rate and forward premium/discount of the peseta in London (daily)

Note: forward rates are annualized 1-month forward premium (-) or discount $(+)$. Source: Financial Times Historical Archive.

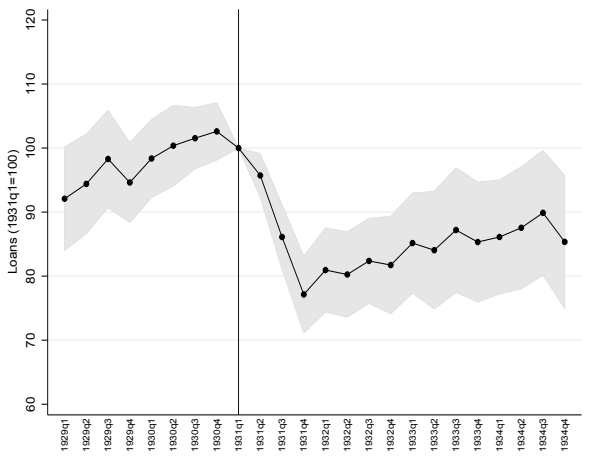

(a) Affected

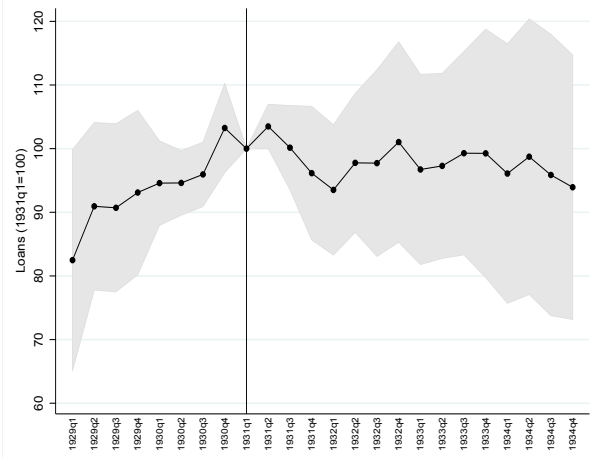

(b) Unaffected

Figure 11: Evolution of bank lending, affected and unaffected banks (1931q1=100)

Note: 87 affected banks, 32 unaffected. Shaded areas show 95\% confidence intervals. Source: own calculations based on Boletines del Consejo Superior Bancario. 


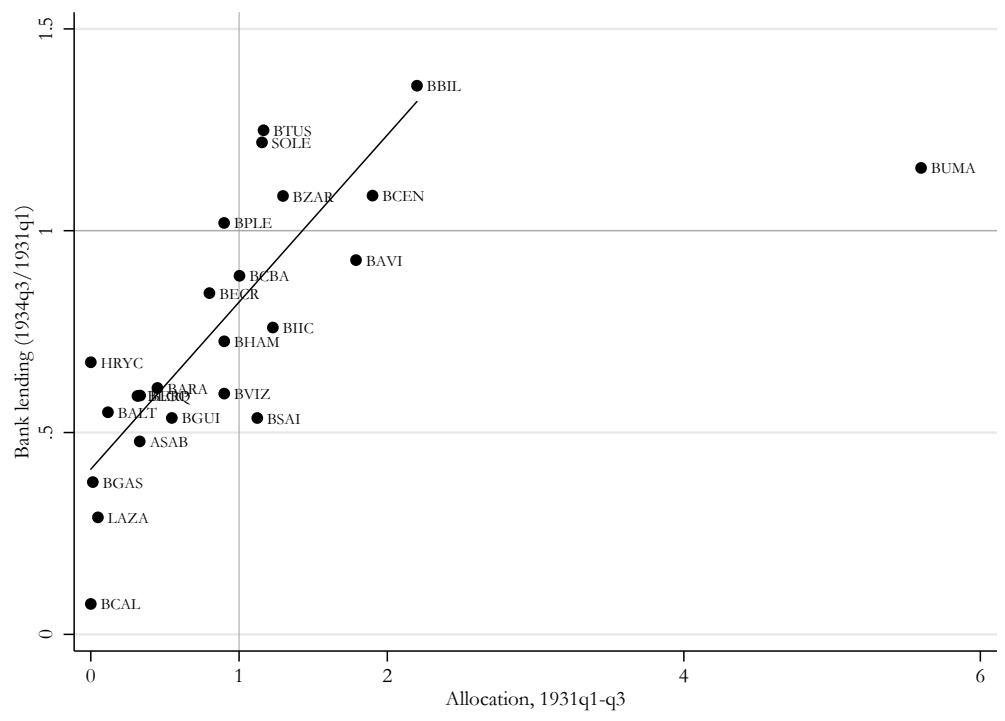

Figure 12: Liquidity assistance and bank lending Note: the line of fitted values excludes BUMA. Source: see text. 


\begin{tabular}{|c|c|c|c|c|c|}
\hline & $\begin{array}{c}1 \\
\text { Loans }(\ln )\end{array}$ & $\begin{array}{c}2 \\
\text { Loans }(\ln )\end{array}$ & $\begin{array}{c}3 \\
\text { Loans }(\ln )\end{array}$ & $\begin{array}{c}4 \\
\text { Loans }(\ln )\end{array}$ & $\begin{array}{c}5 \\
\text { Loans }(\ln )\end{array}$ \\
\hline Bank run * Post-31q1 & $\begin{array}{c}-0.155^{* * *} \\
(0.0261)\end{array}$ & $\begin{array}{c}-0.157^{* * *} \\
(0.0261)\end{array}$ & $\begin{array}{c}-0.156^{* * *} \\
(0.0261)\end{array}$ & $\begin{array}{c}-0.162^{* * *} \\
(0.0273)\end{array}$ & $\begin{array}{c}-0.161^{* * *} \\
(0.0273)\end{array}$ \\
\hline Post-1931q1 & $\begin{array}{c}0.0244 \\
(0.0224)\end{array}$ & $\begin{array}{c}0.0258 \\
(0.0223)\end{array}$ & $\begin{array}{c}0.0255 \\
(0.0224)\end{array}$ & $\begin{array}{c}0.0311 \\
(0.0231)\end{array}$ & $\begin{array}{c}0.0309 \\
(0.0231)\end{array}$ \\
\hline Constant & $\begin{array}{c}8.274^{* * *} \\
(0.154)\end{array}$ & $\begin{array}{c}7.168^{* * *} \\
(0.0801)\end{array}$ & $\begin{array}{c}9.646^{* * *} \\
(0.906)\end{array}$ & $\begin{array}{c}7.168^{* * *} \\
(0.0817)\end{array}$ & $\begin{array}{c}9.644^{* * *} \\
(0.793)\end{array}$ \\
\hline Observations & 3197 & 3197 & 3197 & 3029 & 3029 \\
\hline Num. of banks & 119 & 119 & 119 & 113 & 113 \\
\hline Banks included & All & All & All & Ex. top 6 & Ex. top 6 \\
\hline Fixed effects & No & Bank & Province & Bank & Province \\
\hline
\end{tabular}

Table 2: Differences in lending behavior (1928-34), OLS panel fixed effects estimation

Note: dependent variable is the log of loans. Post $-1931 q 1$ is a dummy that takes value 1 for all quarters after $1931 \mathrm{q} 1$. Bankrun * Post - 1931q1 is the interaction between Post - 1931q1 and the dummy variable Bankrun (see text for details). Source: Boletines del Consejo Superior Bancario.

\begin{tabular}{l|cccccc|c}
\hline & \multicolumn{7}{c}{ Allocation (cummulative) } \\
\hline & BCEN & BHAM & BUMA & BECR & BBIL & BVIZ & W.AVERAGE \\
\hline April & 0.9 & 1.4 & 1.3 & 0.0 & 0.7 & 0.4 & 0.7 \\
May & 0.8 & 0.8 & 2.0 & 0.1 & 1.5 & 1.2 & 0.8 \\
June & 2.1 & 1.2 & 3.5 & 0.5 & 1.2 & 0.9 & 1.2 \\
July & 1.1 & 0.9 & 3.8 & 0.7 & 1.9 & 1.1 & 1.1 \\
August & 1.4 & 0.9 & 4.3 & 0.8 & 2.2 & 1.1 & 1.2 \\
September & 1.9 & 0.9 & 5.6 & 0.8 & 2.2 & 0.9 & 1.4 \\
\hline Average & 1.4 & 1.0 & 3.4 & 0.5 & 1.6 & 0.9 & 1.1 \\
\hline
\end{tabular}

Table 3: Allocation of emergency liquidity, (April-September, 1931)

Note: allocation values in the last column are weighted by the size of banks' deposits before the crisis (end of March 1931). Source: own calculations, based on Actas de la Comisión de Operaciones del Banco de España, Boletines del Consejo Superior Bancario and Liquidez bancaria (Servicio de estudios del Banco de España, 1935). 


\begin{tabular}{|c|c|c|c|c|c|c|c|c|}
\hline & 1 & 2 & 3 & 4 & 5 & 6 & 7 & 8 \\
\hline & OLS & OLS & OLS & \multicolumn{5}{|c|}{ Quantile regression } \\
\hline & & & & $\mathrm{Q}(0.10)$ & $\mathrm{Q}(0.25)$ & $\mathrm{Q}(0.50)$ & $\mathrm{Q}(0.75)$ & $\mathrm{Q}(0.90)$ \\
\hline Size & $0.0273^{*}$ & 0.0241 & 0.0298 & 0.0193 & $0.0516^{* *}$ & 0.0171 & 0.0127 & -0.00795 \\
\hline $\ln$ (assets) & $(0.0159)$ & $(0.0166)$ & $(0.0186)$ & $(0.0247)$ & $(0.0240)$ & $(0.0191)$ & $(0.0243)$ & $(0.0199)$ \\
\hline$\%$ change deposits & -0.0549 & -0.0579 & -0.0509 & -0.0366 & 0.0435 & 0.0152 & -0.0730 & $-0.213^{* *}$ \\
\hline 1930q1-1931q1 & $(0.0828)$ & $(0.0848)$ & $(0.0830)$ & $(0.110)$ & $(0.107)$ & $(0.0852)$ & $(0.108)$ & $(0.0886)$ \\
\hline $\begin{array}{l}\text { Capital ratio } \\
(\text { cap }+ \text { reserves }) / \text { assets }\end{array}$ & $\begin{array}{l}-0.0863 \\
(0.151)\end{array}$ & $\begin{array}{l}-0.127 \\
(0.154)\end{array}$ & $\begin{array}{l}-0.121 \\
(0.152)\end{array}$ & $\begin{array}{c}-0.462^{* *} \\
(0.202)\end{array}$ & $\begin{array}{r}-0.0391 \\
(0.196)\end{array}$ & $\begin{array}{r}-0.0983 \\
(0.156)\end{array}$ & $\begin{array}{l}0.0175 \\
(0.199)\end{array}$ & $\begin{array}{r}0.425^{* *} \\
(0.163)\end{array}$ \\
\hline $\begin{array}{l}\text { Public debt } \\
\text { as \% of securities }\end{array}$ & $\begin{array}{l}0.0184 \\
(0.119)\end{array}$ & $\begin{array}{l}0.0626 \\
(0.121)\end{array}$ & $\begin{array}{l}0.0679 \\
(0.119)\end{array}$ & $\begin{array}{c}0.114 \\
(0.157)\end{array}$ & $\begin{array}{c}0.137 \\
(0.153)\end{array}$ & $\begin{array}{l}0.0629 \\
(0.122)\end{array}$ & $\begin{array}{c}0.100 \\
(0.155)\end{array}$ & $\begin{array}{c}0.201 \\
(0.127)\end{array}$ \\
\hline $\begin{array}{l}\text { Stocks } \\
\text { as \% of securities }\end{array}$ & $\begin{array}{c}0.0366 \\
(0.0957)\end{array}$ & $\begin{array}{l}-0.0147 \\
(0.0995)\end{array}$ & $\begin{array}{l}-0.0455 \\
(0.0981)\end{array}$ & $\begin{array}{l}0.0138 \\
(0.130)\end{array}$ & $\begin{array}{c}0.154 \\
(0.126)\end{array}$ & $\begin{array}{r}-0.0620 \\
(0.101)\end{array}$ & $\begin{array}{r}-0.0896 \\
(0.128)\end{array}$ & $\begin{array}{l}-0.0154 \\
(0.105)\end{array}$ \\
\hline $\begin{array}{l}\text { Long term loans } \\
\text { as } \% \text { of total loans }\end{array}$ & $\begin{array}{l}-0.0986 \\
(0.0876)\end{array}$ & $\begin{array}{l}-0.0949 \\
(0.0901)\end{array}$ & $\begin{array}{l}-0.0565 \\
(0.0915)\end{array}$ & $\begin{array}{l}0.0161 \\
(0.121)\end{array}$ & $\begin{array}{r}-0.0977 \\
(0.118)\end{array}$ & $\begin{array}{l}-0.0293 \\
(0.0940)\end{array}$ & $\begin{array}{r}-0.0422 \\
(0.120)\end{array}$ & $\begin{array}{c}0.0671 \\
(0.0978)\end{array}$ \\
\hline $\begin{array}{l}\text { Currency mismatch } \\
\text { forex dep/peseta loans }\end{array}$ & $\begin{array}{c}0.149 \\
(0.204)\end{array}$ & $\begin{array}{l}0.0717 \\
(0.216)\end{array}$ & $\begin{array}{c}0.118 \\
(0.231)\end{array}$ & $\begin{array}{l}-0.344 \\
(0.306)\end{array}$ & $\begin{array}{l}-0.188 \\
(0.297)\end{array}$ & $\begin{array}{c}0.343 \\
(0.237)\end{array}$ & $\begin{array}{c}0.495 \\
(0.302)\end{array}$ & $\begin{array}{c}0.295 \\
(0.247)\end{array}$ \\
\hline $\begin{array}{l}\text { Population } \\
\text { in logs }\end{array}$ & & $\begin{array}{c}0.0772 \\
(0.0582)\end{array}$ & $\begin{array}{l}-0.0295 \\
(0.0941)\end{array}$ & $\begin{array}{l}0.0356 \\
(0.125)\end{array}$ & $\begin{array}{c}-0.00214 \\
(0.121)\end{array}$ & $\begin{array}{l}-0.0128 \\
(0.0967)\end{array}$ & $\begin{array}{l}0.0147 \\
(0.123)\end{array}$ & $\begin{array}{r}-0.0417 \\
(0.100)\end{array}$ \\
\hline $\begin{array}{l}\text { Population density } \\
\text { in logs }\end{array}$ & & $\begin{array}{c}0.0117 \\
(0.0477)\end{array}$ & $\begin{array}{l}-0.0224 \\
(0.0562)\end{array}$ & $\begin{array}{l}-0.0453 \\
(0.0744)\end{array}$ & $\begin{array}{l}-0.0211 \\
(0.0723)\end{array}$ & $\begin{array}{l}-0.0184 \\
(0.0577)\end{array}$ & $\begin{array}{l}-0.0227 \\
(0.0733)\end{array}$ & $\begin{array}{r}-0.00156 \\
(0.0600)\end{array}$ \\
\hline $\begin{array}{l}\text { Branches } / 1000 \text { habitants } \\
\text { in logs }\end{array}$ & & $\begin{array}{c}0.0205 \\
(0.0608)\end{array}$ & $\begin{array}{l}0.00827 \\
(0.0924)\end{array}$ & $\begin{array}{c}0.000155 \\
(0.122)\end{array}$ & $\begin{array}{c}0.135 \\
(0.119)\end{array}$ & $\begin{array}{r}-0.00872 \\
(0.0949)\end{array}$ & $\begin{array}{c}-0.00811 \\
(0.121)\end{array}$ & $\begin{array}{l}-0.0127 \\
(0.0986)\end{array}$ \\
\hline $\begin{array}{l}\text { Bankruptcies } \\
\text { in logs }\end{array}$ & & $\begin{array}{l}-0.0118 \\
(0.0220)\end{array}$ & $\begin{array}{l}-0.0323 \\
(0.0318)\end{array}$ & $\begin{array}{l}-0.0240 \\
(0.0422)\end{array}$ & $\begin{array}{c}0.0327 \\
(0.0410)\end{array}$ & $\begin{array}{l}-0.0207 \\
(0.0327)\end{array}$ & $\begin{array}{l}-0.0116 \\
(0.0416)\end{array}$ & $\begin{array}{l}-0.0200 \\
(0.0340)\end{array}$ \\
\hline $\begin{array}{l}\text { Work days lost/worker } \\
\text { in logs }\end{array}$ & & $\begin{array}{c}0.0220 \\
(0.0351)\end{array}$ & $\begin{array}{l}0.00343 \\
(0.0361)\end{array}$ & $\begin{array}{l}-0.0426 \\
(0.0478)\end{array}$ & $\begin{array}{l}0.00562 \\
(0.0464)\end{array}$ & $\begin{array}{l}0.00469 \\
(0.0370)\end{array}$ & $\begin{array}{l}-0.0157 \\
(0.0471)\end{array}$ & $\begin{array}{l}-0.0233 \\
(0.0385)\end{array}$ \\
\hline $\begin{array}{l}\text { Agricultural value } \\
\% \text { change } 1930-31\end{array}$ & & $\begin{array}{l}-0.138 \\
(0.120)\end{array}$ & $\begin{array}{l}0.0370 \\
(0.127)\end{array}$ & $\begin{array}{l}0.0971 \\
(0.168)\end{array}$ & $\begin{array}{l}-0.238 \\
(0.163)\end{array}$ & $\begin{array}{r}-0.0603 \\
(0.130)\end{array}$ & $\begin{array}{l}0.0462 \\
(0.166)\end{array}$ & $\begin{array}{l}0.0441 \\
(0.136)\end{array}$ \\
\hline$\%$ Republican votes & & & $\begin{array}{c}0.109 \\
(0.145)\end{array}$ & $\begin{array}{l}0.0726 \\
(0.192)\end{array}$ & $\begin{array}{l}0.0397 \\
(0.186)\end{array}$ & $\begin{array}{c}0.142 \\
(0.149)\end{array}$ & $\begin{array}{c}0.146 \\
(0.189)\end{array}$ & $\begin{array}{r}0.314^{* *} \\
(0.154)\end{array}$ \\
\hline May violent clashes (d) & & & $\begin{array}{c}0.168^{*} \\
(0.0953)\end{array}$ & $\begin{array}{l}-0.165 \\
(0.126)\end{array}$ & $\begin{array}{r}-0.0281 \\
(0.123)\end{array}$ & $\begin{array}{r}-0.00529 \\
(0.0979)\end{array}$ & $\begin{array}{l}0.239^{*} \\
(0.124)\end{array}$ & $\begin{array}{c}0.270^{* * *} \\
(0.102)\end{array}$ \\
\hline $\begin{array}{l}\text { Religious congregations } \\
\text { as } \% \text { of population }\end{array}$ & & & $\begin{array}{c}0.0412 \\
(0.0702)\end{array}$ & $\begin{array}{c}0.121 \\
(0.0929)\end{array}$ & $\begin{array}{l}-0.0410 \\
(0.0903)\end{array}$ & $\begin{array}{c}0.0300 \\
(0.0721)\end{array}$ & $\begin{array}{c}0.0518 \\
(0.0917)\end{array}$ & $\begin{array}{c}0.0596 \\
(0.0749)\end{array}$ \\
\hline Top 6 banks (d) & & & $\begin{array}{l}0.0376 \\
(0.123)\end{array}$ & $\begin{array}{c}0.195 \\
(0.162)\end{array}$ & $\begin{array}{l}0.0633 \\
(0.158)\end{array}$ & $\begin{array}{r}-0.0299 \\
(0.126)\end{array}$ & $\begin{array}{l}0.0322 \\
(0.160)\end{array}$ & $\begin{array}{c}0.114 \\
(0.131)\end{array}$ \\
\hline Madrid (d) & & & $\begin{array}{c}0.106 \\
(0.118)\end{array}$ & $\begin{array}{c}0.237 \\
(0.156)\end{array}$ & $\begin{array}{c}0.211 \\
(0.152)\end{array}$ & $\begin{array}{l}0.215^{*} \\
(0.121)\end{array}$ & $\begin{array}{r}-0.0318 \\
(0.154)\end{array}$ & $\begin{array}{l}0.0816 \\
(0.126)\end{array}$ \\
\hline Barcelona (d) & & & $\begin{array}{l}0.374^{*} \\
(0.192)\end{array}$ & $\begin{array}{c}0.154 \\
(0.254)\end{array}$ & $\begin{array}{c}0.115 \\
(0.247)\end{array}$ & $\begin{array}{c}0.281 \\
(0.197)\end{array}$ & $\begin{array}{c}0.344 \\
(0.251)\end{array}$ & $\begin{array}{c}0.585^{* * *} \\
(0.205)\end{array}$ \\
\hline Bilbao (d) & & & $\begin{array}{r}-0.0177 \\
(0.141)\end{array}$ & $\begin{array}{l}0.0376 \\
(0.187)\end{array}$ & $\begin{array}{r}-0.0387 \\
(0.182)\end{array}$ & $\begin{array}{l}0.0194 \\
(0.145)\end{array}$ & $\begin{array}{r}-0.0155 \\
(0.185)\end{array}$ & $\begin{array}{l}0.0487 \\
(0.151)\end{array}$ \\
\hline Rest of Catalonia (d) & & & $\begin{array}{l}0.195^{* *} \\
(0.0976)\end{array}$ & $\begin{array}{l}0.0103 \\
(0.129)\end{array}$ & $\begin{array}{l}0.220^{*} \\
(0.126)\end{array}$ & $\begin{array}{l}0.185^{*} \\
(0.100)\end{array}$ & $\begin{array}{c}0.170 \\
(0.127) \\
\end{array}$ & $\begin{array}{c}0.0985 \\
(0.104) \\
\end{array}$ \\
\hline Observations & 119 & 119 & 119 & 119 & 119 & 119 & 119 & 119 \\
\hline$R^{2}$ & 0.081 & 0.141 & 0.262 & & & & & \\
\hline
\end{tabular}

Table 1: Determinants of deposit withdrawals (1931q1-1931q3)

Note: All variables for 1931q1 unless otherwise stated. See Table 6 in the Appendix for details on each variable. Source: Boletines del Consejo Superior Bancario for banks' characteristics and Anuario Historico del Instituto Nacional de Estadistica for the rest. 


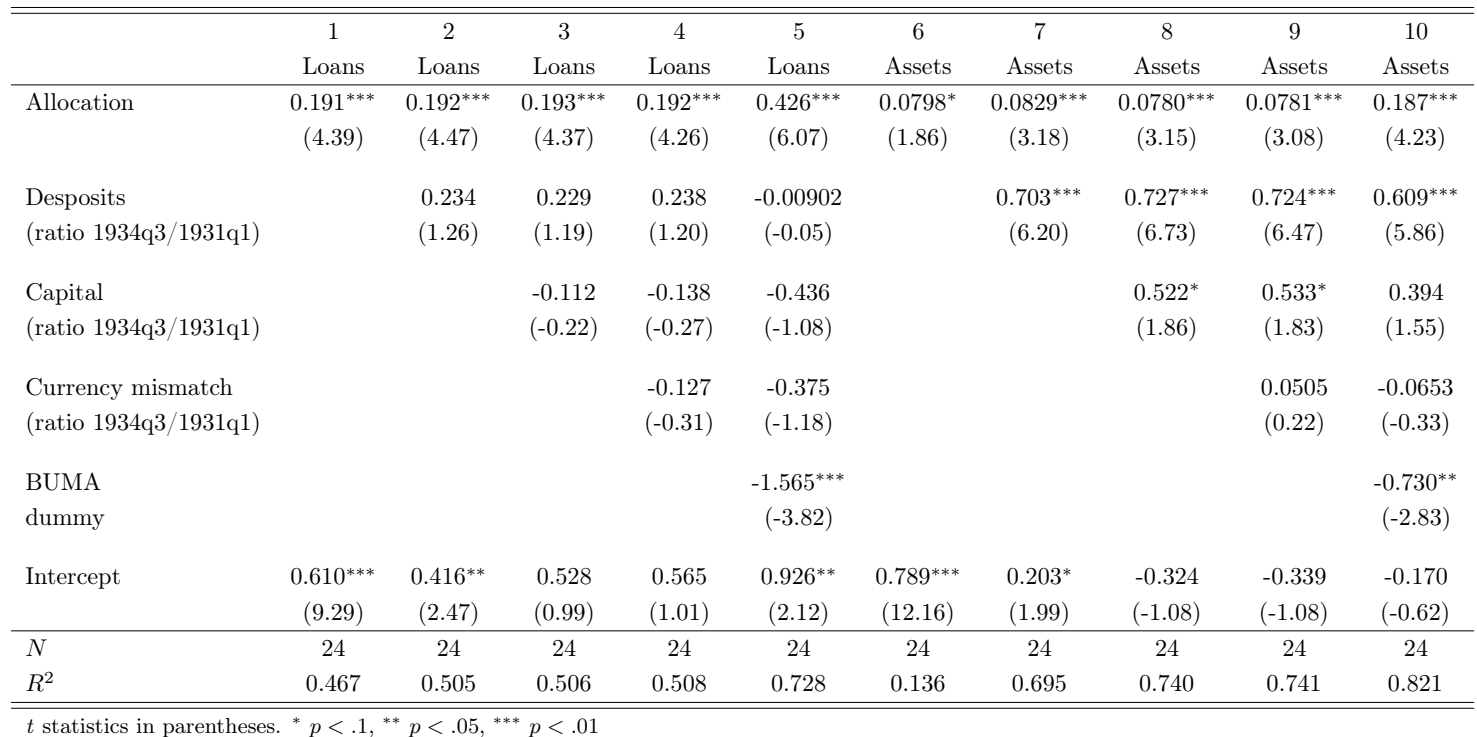

\section{Table 4: Evolution of banks' lending and assets after the 1931 crisis (OLS)}

Note: in columns 1 to 5, dependent variable is the ratio of total loans in 1934q3 over 1931q1; in columns 6 to 10 is the same ratio but for total assets. Source: Actas de la Comisión de Operaciones del Banco de España and Boletines del Consejo Superior Bancario (see text).

\begin{tabular}{|c|c|c|c|c|c|c|c|c|c|c|}
\hline & $\begin{array}{c}1 \\
\text { Securities }\end{array}$ & $\begin{array}{c}2 \\
\text { Securities }\end{array}$ & $\begin{array}{c}3 \\
\text { Public Debt }\end{array}$ & $\begin{array}{c}4 \\
\text { Public Debt }\end{array}$ & $\begin{array}{c}5 \\
\text { Bills } \\
\end{array}$ & $\begin{array}{c}6 \\
\text { Bills } \\
\end{array}$ & $\begin{array}{c}7 \\
\text { Stocks }\end{array}$ & $\begin{array}{c}8 \\
\text { Stocks }\end{array}$ & $\begin{array}{c}9 \\
\text { Cash }\end{array}$ & $\begin{array}{c}10 \\
\text { Cash }\end{array}$ \\
\hline Allocation & $\begin{array}{c}0.0406^{*} \\
(1.86)\end{array}$ & $\begin{array}{c}0.0638 \\
(1.41)\end{array}$ & $\begin{array}{c}0.0162 \\
(0.24)\end{array}$ & $\begin{array}{c}0.0281 \\
(0.20)\end{array}$ & $\begin{array}{l}0.0250 \\
(0.44)\end{array}$ & $\begin{array}{l}0.0871 \\
(0.74)\end{array}$ & $\begin{array}{l}-0.149 \\
(-0.89)\end{array}$ & $\begin{array}{l}-0.0720 \\
(-0.20)\end{array}$ & $\begin{array}{l}-0.149 \\
(-0.89)\end{array}$ & $\begin{array}{r}-0.0720 \\
(-0.20)\end{array}$ \\
\hline $\begin{array}{l}\text { Deposits } \\
\text { (ratio 1934q3/1931q1) }\end{array}$ & $\begin{array}{c}0.950^{* * *} \\
(9.86)\end{array}$ & $\begin{array}{c}0.925^{* * *} \\
(8.68)\end{array}$ & $\begin{array}{c}1.043^{* * *} \\
(3.49)\end{array}$ & $\begin{array}{c}1.031^{* * *} \\
(3.09)\end{array}$ & $\begin{array}{c}0.792^{* * *} \\
(3.16)\end{array}$ & $\begin{array}{c}0.727^{* *} \\
(2.62)\end{array}$ & $\begin{array}{l}-0.476 \\
(-0.64)\end{array}$ & $\begin{array}{l}-0.558 \\
(-0.68)\end{array}$ & $\begin{array}{l}-0.476 \\
(-0.64)\end{array}$ & $\begin{array}{l}-0.558 \\
(-0.68)\end{array}$ \\
\hline $\begin{array}{l}\text { Capital } \\
\text { (ratio 1934q3/1931q1) }\end{array}$ & $\begin{array}{l}0.127 \\
(0.50)\end{array}$ & $\begin{array}{c}0.0970 \\
(0.37)\end{array}$ & $\begin{array}{c}1.842^{* *} \\
(2.37)\end{array}$ & $\begin{array}{c}1.827^{* *} \\
(2.24)\end{array}$ & $\begin{array}{c}1.616^{* *} \\
(2.47)\end{array}$ & $\begin{array}{c}1.537^{* *} \\
(2.27)\end{array}$ & $\begin{array}{l}1.603 \\
(0.83)\end{array}$ & $\begin{array}{l}1.504 \\
(0.75)\end{array}$ & $\begin{array}{l}1.603 \\
(0.83)\end{array}$ & $\begin{array}{l}1.504 \\
(0.75)\end{array}$ \\
\hline $\begin{array}{l}\text { Currency mismatch } \\
\text { (ratio 1934q3/1931q1) }\end{array}$ & $\begin{array}{l}-0.118 \\
(-0.60)\end{array}$ & $\begin{array}{l}-0.142 \\
(-0.70)\end{array}$ & $\begin{array}{l}0.189 \\
(0.31)\end{array}$ & $\begin{array}{l}0.177 \\
(0.28)\end{array}$ & $\begin{array}{l}0.232 \\
(0.45)\end{array}$ & $\begin{array}{l}0.166 \\
(0.31)\end{array}$ & $\begin{array}{c}0.0482 \\
(0.03)\end{array}$ & $\begin{array}{l}-0.0337 \\
(-0.02)\end{array}$ & $\begin{array}{c}0.0482 \\
(0.03)\end{array}$ & $\begin{array}{r}-0.0337 \\
(-0.02)\end{array}$ \\
\hline $\begin{array}{l}\text { BUMA } \\
\text { dummy }\end{array}$ & & $\begin{array}{l}-0.155 \\
(-0.59)\end{array}$ & & $\begin{array}{c}-0.0793 \\
(-0.10)\end{array}$ & & $\begin{array}{l}-0.416 \\
(-0.60)\end{array}$ & & $\begin{array}{l}-0.517 \\
(-0.25)\end{array}$ & & $\begin{array}{l}-0.517 \\
(-0.25)\end{array}$ \\
\hline Intercept & $\begin{array}{c}-0.0552 \\
(-0.20)\end{array}$ & $\begin{array}{c}-0.0193 \\
(-0.07)\end{array}$ & $\begin{array}{l}-1.697^{*} \\
(-2.02)\end{array}$ & $\begin{array}{l}-1.679^{*} \\
(-1.90)\end{array}$ & $\begin{array}{c}-1.628^{* *} \\
(-2.31)\end{array}$ & $\begin{array}{l}-1.532^{*} \\
(-2.09)\end{array}$ & $\begin{array}{c}-0.0673 \\
(-0.03)\end{array}$ & $\begin{array}{c}0.0520 \\
(0.02)\end{array}$ & $\begin{array}{c}-0.0673 \\
(-0.03)\end{array}$ & $\begin{array}{c}0.0520 \\
(0.02)\end{array}$ \\
\hline$N$ & 24 & 24 & 24 & 24 & 24 & 24 & 24 & 24 & 24 & 24 \\
\hline$R^{2}$ & 0.842 & 0.845 & 0.469 & 0.469 & 0.448 & 0.459 & 0.090 & 0.093 & 0.090 & 0.093 \\
\hline
\end{tabular}

Table 5: Evolution of banks' portfolio of securities after the 1931 crisis (OLS)

Note: dependent variable is the ratio of each category in 1934q3 over 1931q1. Securities includes Public Debt, Bills of Exchange and Stocks. Source: Actas de la Comisión de Operaciones del Banco de España and Boletines del Consejo Superior Bancario (see text). 


\section{Appendix: data}

\begin{tabular}{|c|c|c|c|c|c|c|c|}
\hline Variable & Obs. & Mean & St. dev. & Median & Max & Min & Table \\
\hline$\%$ change in deposits (1931q1-1931q3) & 119 & -0.08 & 0.22 & -0.06 & -0.76 & 0.94 & \multirow{22}{*}{1} \\
\hline Size (log of assets) & 119 & 9.96 & 1.68 & 9.82 & 14.37 & 6.53 & \\
\hline$\%$ change in deposits (1930q1-1931q1) & 119 & 0.08 & 0.25 & 0.06 & -0.56 & 1.35 & \\
\hline Capital ratio ((capital+reserves) as \% of assets) & 119 & 0.26 & 0.17 & 0.20 & 0.99 & 0.00 & \\
\hline Public debt as $\%$ of securities & 119 & 0.36 & 0.22 & 0.37 & 0.97 & 0.00 & \\
\hline Stocks as $\%$ of securities & 119 & 0.30 & 0.24 & 0.25 & 1.00 & 0.00 & \\
\hline Long term loans as $\%$ of total loans & 119 & 0.21 & 0.26 & 0.05 & 0.94 & 0.00 & \\
\hline Currency mismatch (forex dep as $\%$ of pta. loans) & 119 & 0.07 & 0.11 & 0.02 & 0.56 & 0.00 & \\
\hline Population (in logs) & 119 & 6.53 & 0.72 & 6.41 & 7.49 & 4.64 & \\
\hline Population density (in logs) & 119 & 4.53 & 0.79 & 4.54 & 5.46 & 2.71 & \\
\hline Branches/1000 inhabitants (in logs) & 119 & -2.89 & 0.53 & -2.98 & -1.76 & -4.07 & \\
\hline Bankruptcies/population (in logs) & 119 & -0.54 & 1.39 & -0.25 & 1.50 & -2.60 & \\
\hline Work days lost per worker (in logs) & 119 & 2.46 & 0.69 & 2.33 & 4.39 & 0.00 & \\
\hline Agricultural value (\% change) & 119 & 0.10 & 0.18 & 0.05 & 0.71 & -0.26 & \\
\hline$\%$ of Republican votes & 119 & 0.52 & 0.23 & 0.60 & 0.87 & 0.00 & \\
\hline Religious congregations/population (in logs) & 119 & -8.30 & 0.54 & -8.31 & -7.37 & -9.56 & \\
\hline May violent clashes (dummy) & 119 & 0.25 & 0.43 & 0.00 & 1.00 & 0.00 & \\
\hline Top 6 banks (dummy) & 119 & 0.05 & 0.22 & 0.00 & 1.00 & 0.00 & \\
\hline Madrid (dummy) & 119 & 0.15 & 0.36 & 0.00 & 1.00 & 0.00 & \\
\hline Barcelona (dummy) & 119 & 0.21 & 0.41 & 0.00 & 1.00 & 0.00 & \\
\hline Bilbao (dummy) & 119 & 0.04 & 0.20 & 0.00 & 1.00 & 0.00 & \\
\hline Rest of Catalonia (dummy) & 119 & 0.06 & 0.25 & 0.00 & 1.00 & 0.00 & \\
\hline Bank run (dummy) & 119 & 0.73 & 0.45 & 1.00 & 1.00 & 0.00 & 2 \\
\hline Allocation & 24 & 1.00 & 1.15 & 0.89 & 5.60 & 0.00 & 4,5 \\
\hline
\end{tabular}

Table 6: Descriptive statistics of all variables

Source: see text. 


\begin{tabular}{l|l|r} 
Bank code & Name & Assets as \% of total \\
\hline ASAB & Anglo South-American Bank & $4.8 \%$ \\
BLOQ & Banca Lopez Quesada & $0.1 \%$ \\
BTUS & Banca Tusquets & $0.1 \%$ \\
BALT & Banco Aleman Transatlantico & $0.1 \%$ \\
BCAL & Banco Calamarte & $0.1 \%$ \\
BCEN & Banco Central & $4.1 \%$ \\
BCBA & Banco Comercial de Barcelona & $0.8 \%$ \\
BARA & Banco de Aragon & $1.4 \%$ \\
BAVI & Banco de Avila & $0.2 \%$ \\
BBIL & Banco de Bilbao & $7.7 \%$ \\
BVIZ & Banco de Vizcaya & $6.0 \%$ \\
BECR & Banco Español de Credito & $12.8 \%$ \\
BERP & Banco Español del Rio de la Plata & $2.7 \%$ \\
BGAS & Banco Germanico de America del Sur & $0.3 \%$ \\
BGUI & Banco Guipuzcoano & $1.9 \%$ \\
BHAM & Banco Hispano Americano & $12.6 \%$ \\
BIIC & Banco Internacional de Industria y Comercio & $1.2 \%$ \\
BPLE & Banco Popular de Leon XIII & $0.1 \%$ \\
BSAI & Banco Sainz & $0.6 \%$ \\
BUMA & Banco Urquijo de Madrid & $4.3 \%$ \\
BZAR & Banco Zaragozano & $0.9 \%$ \\
HRYC & Herrero Riva y Cia & $0.2 \%$ \\
LAZA & Lazard Brothers & $1.1 \%$ \\
SOLE & Soler y Torra Hermanos & $0.3 \%$ \\
\hline Total & & $64.3 \%$
\end{tabular}

Table 7: Banks included in Tables 4 and 5

Note: share of assets, loans and deposits is as \% of total banking sector in 1931q1. Source: Boletines del Consejo Superior Bancario. 


\begin{tabular}{|c|c|c|c|}
\hline & & Subscribed & As $\%$ of total \\
\hline Spanish banks & & 151.0 & $43 \%$ \\
\hline \multirow[b]{8}{*}{ Foreign banks } & Banco de Bilbao (BBIL) & 38.0 & $11 \%$ \\
\hline & Banco Hispano Americano (BHAM) & 33.7 & $10 \%$ \\
\hline & Banco Urquijo de Madrid (BUMA) & 16.8 & $5 \%$ \\
\hline & Banco de Vizcaya (BVIZ) & 13.4 & $4 \%$ \\
\hline & Banco Español de Credito (BECR) & 11.1 & $3 \%$ \\
\hline & Banca March $(\mathrm{BMCH})$ & 10.3 & $3 \%$ \\
\hline & Others (in Barcelona and Bilbao) & 27.7 & $8 \%$ \\
\hline & & 43.8 & $13 \%$ \\
\hline \multirow[b]{8}{*}{ Firms } & Irving Trust & 13.0 & $4 \%$ \\
\hline & Midland Bank & 6.3 & $2 \%$ \\
\hline & Moroccan State Bank & 6.0 & $2 \%$ \\
\hline & Credit Lyonnais & 6.0 & $2 \%$ \\
\hline & Lazard Brothers & 6.5 & $2 \%$ \\
\hline & Anglo South American Bank & 3.5 & $1 \%$ \\
\hline & International Banking Corporation & 2.5 & $1 \%$ \\
\hline & & 41.0 & $12 \%$ \\
\hline \multirow[b]{10}{*}{ Public } & CHADE & 6.0 & $2 \%$ \\
\hline & Rio Tinto & 7.5 & $2 \%$ \\
\hline & Rothschild & 3.0 & $1 \%$ \\
\hline & R.C. Asturiana & 4.0 & $1 \%$ \\
\hline & Minas del Rif & 7.5 & $2 \%$ \\
\hline & Peñarroya & 2.5 & $1 \%$ \\
\hline & Riegos y Fuerzas del Ebro & 2.5 & $1 \%$ \\
\hline & Tabacos de Filipinas & 3.0 & $1 \%$ \\
\hline & Sota y Aznar & 5.0 & $1 \%$ \\
\hline & & 24.7 & $7 \%$ \\
\hline Others (not reported) & & 89.5 & $26 \%$ \\
\hline Total & & 350.0 & $100 \%$ \\
\hline
\end{tabular}

Table 8: Subscribers of gold bonds issued in December 1929 (million pesetas)

Source: Información Financiera, Gran Vida, Año XXVII, Num.318, p.2\%. 


\section{Appendix: archival sources}

\section{- Archivo Histórico del Banco de España}

- Actas de la Comisión de Operaciones del Banco de España (L.12106, L.12107)

- Actas del Consejo de Gobierno del Banco de España (L.27159)

- Liquidez Bancaria, Servicio de Estudios del Banco de España (D.6505)

- Boletines del Consejo Superior Bancario, Tomo I (1924-29), Tomo II (1930-36) $(1 / 1 / 3 / 1)$

- Actas del Consejo Superior Bancario, Vols. I-II (1922-28), III (1928-31), IV (1931-32), V (1932-35) (L.109572, 109573, 109574, 109575)

\section{- Archivo Histórico del BBVA}

- Memoria-Balance de la Sucursal de Madrid del Banco de Bilbao, Ejercicio 1931

\section{- Archivo Histórico del Banco de Santander}

- Banco Comercial de Barcelona, Libros Mayores 9-10 (L.6797,L.6798)

- Banca Tusquets, Libro Mayor 9 (L.284)

- Banco Soler y Torra, Libro Mayor 11 (L.1256)

- The Rothschild Archive (London)

- Letter from De Rothschild Frères and Bauer y Compañía, 25/03/1931 (111/459)

\section{- The BIS Archives}

- Letter from BIS Vice-President Leon Fraser to BdE Governor Federico Carlos Bas y Vasallo, 30/12/1930 (BISA, 2.81) 


\section{Notes}

${ }^{1}$ The proclamation of the Republic had also an almost immediate effect on the stock market, which is why some authors classify this crisis as triple, and not twin (Betrán et al., 2012). Considering its size, the stock market shock had a relatively small effect on most banks, as mark-to-market for shares and bonds (private and public) was suspended until December 1933, thus avoiding widespread bank insolvencies. I deal with the importance of the shock to the stock market and policy reaction in Jorge-Sotelo (2019).

${ }^{2}$ I explore the underlying reasons for the absence of widespread bank failures in Jorge-Sotelo (2019).

${ }^{3}$ I am not the first to question the traditional account. Martín-Aceña (1984) concluded that monetary policy in Spain during the 1930s was definitely not expansive, while García Ruiz (1992, 1993) suggested that this might have had an effect on the supply of credit after the 1931 crisis. As a matter of fact, Spain underwent a very severe economic contraction during the 1930s.

${ }^{4}$ The Minister of Finance of the Dictatorship, Jose Calvo Sotelo, considered the appreciation of the peseta in 1926-27 as the undeniable result of the "rhythm of progress and vigor that the dictatorship was imposing on Spain" (Calvo Sotelo, 1933). By December 1928, when the peseta was starting to fall rapidly, Calvo Sotelo claimed that "the value of the peseta needs to be the expression of moral reality, present and future, and of racial capabilities, incompatible with a sharp depreciation of our currency" (Cambó, 1991, p.335). By that time, the defense of the value of the peseta had become a matter of political prestige for the dictatorship (Tapia, 1998, p.16). The Minister, however, failed to understand power-purchasing-parity theory of exchange rate determination, something that was highlighted by the Comision del Patron Oro (1929). As Sardà (1936) observed, "the Spanish government, undoubtedly pushed by political motivations, started the [unfruitful] intervention in the exchange rate in 1928", until the cost of this intervention was too large, interventions had to stop and Calvo Sotelo resigned. Several pieces of evidence supporting this thesis can be found on Eguidazu (1979), Tapia (1998), Martín-Aceña (1984) or Martínez-Ruiz and Nogués-Marco (2014). In particular, Tapia (1998) explains how Calvo Sotelo failed to understand power purchasing parity determination of exchange rates, and was convinced that the peseta could be stabilized at a level consistent with the deserved reputation of the country.

${ }^{5}$ See for example, Martin (2009) for an argument about how flexible exchange rates eliminate all constraints to lender of last resort interventions. In contrast Ugolini (2017) highlights the fact that in the presence of fiscal limitations or political instability, flexible exchange rates are not a sufficient condition to allow for LLR interventions.

${ }^{6}$ In 1928, Calvo-Sotelo claimed that "the value of the peseta needs to be the expression of moral reality, present and future, and of racial capabilities, incompatible with a sharp depreciation of our currency" (Cambó, 1991, p.335).

${ }^{7}$ Citation taken from Pabón (2000, p.566).

${ }^{8}$ Calvo Sotelo (1933, p.186-187).

${ }^{9}$ This was perceived also abroad, as can be seen in the correspondence between the De Rothschild Freres and the Spanish bank Bauer y Cia, their correspondent in Spain. On 20 August 1930, Ignacio Bauer, the chair of the bank, wrote: "It is hard to believe how much the question of the exchange rate weights in all aspects of Spanish politics." (...) "Mr. Arguelles [the Minister of Finance] has been replaced by Mr. Wais. I have nothing to say against the new Minister, on the contrary, he is intelligent, young and honest. His predecessor, however, had the same qualities, and despite all this, the exchange rate continued to worsen. Nowadays everything depends on the exchange rate." (Rothschild Historical Archive, 111/459). 
The Financial Times also reported on the importance of the exchange rate for the resignation of Dictator Miguel Primo de Rivera: "(...) it is probably correct to say that one of the causes which led to his resignation was (...) the weakness of, and obscurity in regard to, the exchange value of the national currency" (Financial Times, 31/03/1930, p.31).

${ }^{10}$ La Gaceta de Madrid, Num.339, 5 de Diciembre 1929, p.1474 et passim.

${ }^{11}$ Until September 1931, virtually all subscribers of gold bonds asked to be paid interest in Sterling. After that, US Dollars and then French Francs replaced payments in Sterling ("Manifestaciones del Ministro de Hacienda", Ahora, 26/09/1931, p.10).

${ }^{12}$ From a total of 350 million pesetas-gold, the Government had drafted an allocation of 150 million for Spanish banks, 100 million for the BdE, and 100 for the public. However, the final allocation of gold-bonds differed from the initial draft, because foreign banks, members of the public and large firms demanded more than what they had been initially allocated (Table 8).

${ }^{13}$ Figures of bondholders are provided in Table 8 . These are estimates provided by the press, but it is plausible that Spanish banks did actually buy more bonds, as their balance sheets show larger increases in foreign-currency denominated liabilities during the first quarter of 1930. It is also very possible that the category "Others" includes bonds bought by other, smaller banks. By 16 April 1931, two days after the proclamation of the Republic, the Financial Times reported that bonds had not changed hands ("Rights of Spanish Sealed Bonds", 16/04/1931, page 1, Edition 13, 184.).

${ }^{14}$ Some contemporary accounts argue that the Primo de Rivera forced banks to subscribe the gold bonds. An example of this can be found on Vida Economica, 30/06/1931, Año XX, Num. 775, p.231-232. However, the fact that there was strong demand from the public and foreign banks casts doubt on this account.

${ }^{15}$ Between 1929 and 1930, customs revenues fell by 17\%, while between 1929 and 1931, they fell by $28 \%$ (Comín and Diaz, 2005).

${ }^{16}$ Foreign banks also played a role, as they had directly subscribed around $13 \%$ of the issued bonds (Table $8)$.

${ }^{17}$ Acta de la Reunion Extraordinaria de la Comisión de Operaciones del Banco de España, 17/04/1931.

${ }^{18}$ Section VII of Article I of the 1921 Banking Law stated that if the Government embarked in a specific action in the defense of the currency, if the BdE mediated in the intervention or if it intervened directly, half of the gold used with that end would be from the BdE's reserve (Base Septima, Articulo I, Ley de Ordenación Bancaria, 27/12/1921).

${ }^{19}$ Actas del Consejo de Gobierno del Banco de España, 24/10/1930.

${ }^{20}$ In a meeting of the board of the CSB in October, the Secretary explained that the Banco de España was willing to contribute to support the currency, but that gold from the Banco should not be involved: "the operation should be done under more advantageous conditions, without using the Banco's gold as guarantee, because doing this, the same as moving its gold, fills the Banco with disgust" (Acta de del Consejo Superior Bancario de 8 de Octubre de 1930, p.194).

${ }^{21}$ Toniolo and Clement (2005, p.80).

${ }^{22}$ Toniolo and Clement (2005, p.81).

${ }^{23}$ Letter from BIS Vice-President Leon Fraser to BdE Governor Federico Carlos Bas y Vasallo, 30/12/1930. Bank for International Settlements Archive, BISA 2.81, Bank of Spain, Policy.

${ }^{24}$ Martín-Aceña (1984, p.201).

${ }^{25}$ JP Morgan canceled the credit on 17 April. Mendelsshon \& Co. on 20 May. The BIS also cut its credit line and it was let to expire by the end of June. Officially, the credit was canceled by JP Morgan, and not by 
the Spanish Government. The reason for the cancellation of the credit, according to a letter that JP Morgan sent to the BdE, was the abandonment of a clear stabilization plan for the peseta, and not the composition of the government. This last statement is of course, difficult to prove, but JP Morgan also provided the BdE with a memorandum in which it explained which was the best way to stabilize the peseta. Interestingly it suggested using the discount rate and the gold reserve. In another letter, Mendelsshon \& Co. mentioned that they had canceled the credit, partly because of the tensions in foreign exchange markets due to the Credit-Anstalt crisis, although they were not the main providers of the line of credit (Martín-Aceña, 1984).

${ }^{26}$ Ley de Ordenación Bancaria, Gaceta de Madrid, 30/12/1921, p.364 et passim.

${ }^{27}$ Acta de la Sesion Extraordinaria del Consejo Superior Bancario, 15/04/1931, p. 267 et passim. and 05/05/1931, p.279-280.

${ }^{28}$ The two largest and most widely branched banks in Spain entered the discussion. Mr. Ramon Alvarez Valdes (BHAM) claimed that "we just have to overcome the first 15 days". Note that BHAM did not experience liquidity pressure during April (Figure 3). The opposite was true for Mr. Pablo Garnica (BECR), who claimed that it had always been the case that when banks were in deer need of funds, it was the BdE who held the "ultimate reserve" and added that as long as the BdE was within the fiduciary limits, it should not be concerned over lending to banks at demand. Garnica's point is important because, on the following days, restricted by the fiduciary limits, the BdE injected 180 million pesetas, but Garnica's bank (BECR) did not borrow at all. Both Garnica (BECR) and Pan (BdE) agreed in that, whatever happened, they did not want the Government to know about specific banks' difficulties (Acta de la Sesion Extraordinaria del Consejo Superior Bancario, 15/04/1931, p.266.

${ }^{29}$ Acta de la Sesion Extraordinaria del Consejo Superior Bancario, 18/04/1931, p. 278 et passim.

${ }^{30}$ In fact, Mr. Prieto did not want to acknowledge receipt of the petition that he received on 18 April, and he asked banks to rewrite the petition with the date of 5 May, so he would not be liable for the delay in the authorization (Acta de la Sesion Extraordinaria del Consejo Superior Bancario, 05/05/1931, p.280).

${ }^{31}$ International observers commented on this problem. On 31 May, the Financial Times acknowledged the "(...) exceptional demand for the Franc (...) to purchase against sales of the peseta by people withdrawing capital from Spain." ("Spain's money troubles", Financial Times, 01/06/1931, p.5).

${ }^{32}$ Gaceta de Madrid, 07/05/1931, p.581 and 28/05/1931, p.974-975. Spain was the first country to impose such controls, in the last days of May 1931 (Bernanke, 2000).

${ }^{33}$ Gaceta de Madrid, 31/05/1931, p.1051-1053.

34 "Peseta creates new record" (Financial Times, 30/05/1931, p.1) and "Decline of the peseta" (Financial Times, 02/06/1931, p.4).

${ }^{35}$ La Epoca, 27/05/1931.

${ }^{36}$ El Sol reported that: "A meeting between members of commerce and real estate industry took place in Madrid, in order to take all actions possible to stop the crisis in real estate as a result of the restrictions in banks' credit", El Sol, 29/05/1931, p.1.

${ }^{37}$ This appeared in all main newspapers. The one I cite is from Ahora, 28/05/1931, p.6.

${ }^{38}$ El Liberal, 28/05/1931, p.4.

${ }^{39}$ La Libertad, 28/05/1931.

40 "Peseta's low level" (Financial Times, 02/06/1931, p.7).

41 "Spanish credit in Paris" (Financial Times, 11/06/1931, p.6).

${ }^{42}$ The Government guaranteed $50 \%$ of the gold shipments to France. 
43 "Peseta stabilisation", (Financial Times, 24/08/1931, p.5). The actual target was 51.9 (Martín-Aceña, 1984).

${ }^{44}$ See Martín-Aceña (1984, p.237-251) for a detailed account.

45 "Peseta credits" (Financial Times, 28/08/1931, p.5).

${ }^{46}$ In fact, four of the largest six banks had their headquarters in Madrid, where they also conducted the majority of their operations with the BdE, especially during the 1931 crisis.

${ }^{47}$ These are: Soler y Torra Hermanos (SOLE), Banca Tusquets (BTUS) and Banco Comercial de Barcelona (BCBA). For this, I am especially indebted to Dr. José Antonio Gutiérrez, from the Historical Archive of the Banco de Santander, who patiently walked me through the bank's archive to find as much useful data as possible.

${ }^{48}$ Alternative measures of currency mismatch such as share of foreign exchange deposits over total deposits or over total assets do not change the regression results.

${ }^{49}$ Capital ratios enter the regression with unexpected coefficients, signaling that having high capital ratios made a bank more likely to suffer a sharp deposit loss (Columns 4 and 8 in Table 1. However, these results are driven by four banks in the 99th percentile of the distribution of capital ratios. This means holding capital ratios of more than $70 \%$, which are very far from the $90 \%$ percentile (capital ratios of $50 \%$ ) and farther from the mean of $25 \%$ capital ratios and the median of $20 \%$ capital ratios. Interestingly, the coefficient associated to the variable that measures pre-crisis liquidity pressure (i.e. deposit losses between 1930q1 and 1931q1) suggests that suffering a sharp deposit loss during the crisis is not positively correlated with pre-crisis pressure, but rather the contrary.

${ }^{50}$ For example, in its 1931 Annual Report, Banco de Bilbao (BBIL) mentioned that this was the case in a number of provinces in which the bank had opened branches, as depositors feared that their savings would be in danger and run to withdraw deposits (Memoria Anual de la Sucursal del Banco de Bilbao en Madrid, 1931).

${ }^{51}$ The newspaper La Epoca explained that all banks in Madrid had in fact been inspected in order to see who had withdrawn "unusual" amounts, and that all banks allowed the government to conduct the inspection, including Banco Urquijo de Madrid (BUMA) (La Epoca, 22/04/1931.). For example, Banco de Bilbao (BBIL) considered the rumors of expropriation exaggerated: "(...) the alarmist rumours, that, without any foundation, were propagated about the possible intervention of the State in current accounts (...)" (Memoria y Balance de la Sucursal del Banco de Bilbao en Madrid, 1931, p.5).

${ }^{52}$ It must be noted that an Allocation $i$ value of 1 does not necessarily imply that the bank could just keep its total loan portfolio afloat. The representative bank had to make a choice between using the emergency liquidity to continue supplying short term credit, invest in other securities, buy foreign exchange to meet its maturing short-term foreign exchange liabilities, and/or maintain its loan portfolio. A given bank could also use its cash reserve to pay depositors back, although it is reasonable to think that banks wanted to keep a relatively comfortable cash reserve given the circumstances. Therefore, Allocation $_{i}$ ought to be interpreted as a lower bound, because it is likely that actual liquidity pressure was stronger.

${ }^{53}$ Comparison is done with $1934 \mathrm{q} 3$ because in October, new political developments caused shock to bank lending although it was relatively small. Also, in 1934q4 there was an important merger between BCEN and BERP.

${ }^{54}$ I deal with the idiosyncrasies of this bank in Jorge-Sotelo (2019).

${ }^{55}$ Results are not driven by Banco de Urquijo de Madrid (BUMA), the aforementioned outlier. Introducing a dummy for this bank, increases the coefficient on Allocation $_{i}$, signaling that after a certain point, 
decreasing returns kicked in and more liquidity did not translate into more lending. This bank had an Allocation $_{i}$ value of 5.6 .

${ }^{56}$ A potential identification problem stems from the fact that when banks create loans they also create deposits. Therefore, the drop in deposit values in bank balance sheets might just be capturing that firms reduced demand for loans, canceled them and therefore the given bank experienced a drop in deposits. Because of that, the drop in deposits might not be signaling that the bank is suffering a run but just a reduction in the demand for credit. This would compromise my conclusion. However, there are three reasons why this does not seem to be the case. First, the qualitative evidence presented above proves, first hand, that banks were cutting on credit because of their inability to replace depositors with liquidity from the BdE. Second, the drop in demand for credit would be signalling an automatic worsening of economic expectations right after the proclamation of the Republic. This would fail to explain why certainly the most affected bank by the regime change, Banco de Urquijo (BUMA), maintained its loan porftolio intact throughout the 1930s thanks to liquidity from the BdE. A similar case applies to Banco de Bilbao (BBIL), a bank that did not suffer strong deposit losses and continued to lend throughout the crisis (see Jorge-Sotelo (2019) for more details). Finally, another reason is that the fact that deposits recovered their pre-1931 level by the end of 1934 while loans remained depressed shows that the cash that deposit losses were not the consequence of the contraction in loans demand. If deposit losses were just the product of a contraction in loans, then deposits would have also remained depressed. 


\section{References}

Accominotti, O. (2012): "London Merchant Banks, the Central European Panic, and the Sterling Crisis of 1931," The Journal of Economic History, 72, 1-43.

Accominotti, O. And B. Eichengreen (2016): "The mother of all sudden stops: capital flows and reversals in Europe, 1919-1932," The Economic History Review, 69, 469-492.

Albers, T. N. (2018): "The prelude and global impact of the Great Depression: evidence from a new macroeconomic dataset," Explorations in Economic History, 70, 150-163.

Anari, A., J. Kolari, And J. MAson (2005): "Bank asset liquidation and the propagation of the U.S. Great Depression," Journal of Money, Credit and Banking, 37, 753-773.

BAlcells, A. (1971): Crisis economica y agitacion social en Cataluña, de 1930 a 1936, Ediciones Ariel.

Ben-Ami, S. (2012): El cirujano de hierro: la dictadura de Primo de Rivera 1923-1930, RBA Libros.

Bernanke, B. (1983): "Non-monetary effects of the financial crisis in the propagation of the Great Depression," The American Economic Review, 3, 257-276.

(2000): Essays on the Great Depression, Princeton University Press.

Bernanke, B. And H. James (1991): "The Gold Standard, Deflation, and Financial Crisis in the Great Depression: An International Comparison," in Financial Markets and Financial Crises, ed. by R. e. Hubbard, University of Chicago Press.

Betrán, C., P. Martín-Aceña, And M. A. Pons (2012): "Financial crises in Spain: lessons from the last 150 years," Revista de Historia Economica, Journal of Iberian and Latin American Economic History, 3, 417-446.

Betrán, C. And M. A. Pons (2018): "Understanding Spanish financial crises severity, 1850-2000," European Review of Economic History.

Bolt, J. And J. L. VAn Zanden (2013): "The Maddison Project: collaborative research on historical national accounts," The Economic History Review, 67, 627-651.

Bordo, M. (2006): "Sudden stops, financial crises, and original sin in emerging countries: déjà vu?" NBER Working Papers, July, 2006. 
Bordo, M. And C. M. Meissner (2006): "The role of foreign currency debt in financial crises: 1880-1913 vs 1972-1997," Journal of Banking and Finance, 60, 3299-3329.

Cabezas, O. (2005): Indalecio Prieto, socialista y español, Algaba Ediciones.

Calvo, G. A. (2006): "Monetary policy challenges in emerging markets: sudden stop, liability dollarization, and lender of last resort," NBER Working Papers.

Calvo, G. A. And C. M. Reinhart (2001): Fixing for your life, Brookings Institution (Washington DC), chap. 1, 1-39.

- (2002): "Fear of floating," The Quarterly Journal of Economics, 117, 379-408.

Calvo Sotelo, J. (1933): Mis servicios al Estado, Imprenta Clasica Española, Madrid.

Cambó, F. D. A. (1991): Discursos parlamentaris (1907-1935), Editorial Alpha.

Chang, R. AND A. Velasco (2000): Liquidity crises in emerging markets: theory and policy, NBER, 11-78.

Choudhri, E. U. And L. A. Kochin (1980): "The exchange rate and the international transmission of business cycle disturbances: Some evidence from the Great Depression," Journal of Money, Credit, and Banking, 565-574.

Comín, F. (2012): "Default, rescheduling and inflation: public debt crises in Spain during the 19th and 20th centuries," Journal of Iberian and Latin American Economic History, 30, 353-390.

Comín, F. And D. Diaz (2005): "Sector publico administrativo y estado del bienestar," in Estadisticas historicas de España. Siglos XIX-XX, ed. by A. Carrreras and X. Tafunell, Fundacion BBVA, chap. 12, 873-967.

Comisión del Patron Oro (1929): Dictamen de la Comisión nombrada por Real Orden de 9 de Enero de 1929 para el estudio de la implantacion del patron oro, Consejo Superior Bancario.

Eguidazu, F. (1979): "La crisis de la peseta y la caida de la Dictadura," Cuadernos Economicos del ICE, 299-352.

Eichengreen, B. (1992): Golden fetters: the Gold Standard and the Great Depression, 1919-1939, Oxford University Press. 
Eichengreen, B. And K. Mitchener (2003): "The Great Depression as a credit boom gone wrong," BIS Working paper 13\%. Bank for International Settlements.

Eichengreen, B. And P. Temin (1997): "The Gold Standard and the Great Depression," NBER Working Paper.

Farhi, E. And I. Werning (2014): "Dilemma not Trilemma? Capital controls and exchange rates with volatile capital flows," IMF Economic Review (Special Volume in Honor of Stanley Fischer) 62, p.569-605.

García Ruiz, J. L. (1992): "Patrón Oro, banca y crisis (1875-1936). Una revision desde la historia economica." Cuadernos de Estudios Empresariales.

_ (1993): "Banca y crisis económica en España, 1930-1935: un nuevo enfoque," Revista de Historia Económica.

Grossman, R. (1994): "The shoe that didn't drop: explaining banking stability during the Great Depression," The Journal of Economic History, 3, 654-682.

Instituto Nacional de Estadística (1934): Anuario Estadistico de España, Año XVIII, 1932-1933, Imprenta de Rivadeneira, Artes Graficas (Madrid).

JAmes, H. (1984): "The causes of the German banking crisis of 1931," Economic History Review, 63-132.

(2002): The end of globalization: lessons from the Great Depression, Harvard University Press.

Jorge-Sotelo, E. (2019): "The political economy of central bank development and financial crises in the periphery of the Gold Standard: Spain 1921-1935," Ph.D. Dissertation, London School of Economics and Political Science (mimeo).

Kaminsky, G. L. And C. M. Reinhart (1999): "The twin crises: the causes of banking and balance-of-payments problems," American Economic Review, 473-500.

Krugman, P. (1999): "Balance sheets, the transfer problem, and financial crises," in International finance and financial crises, ed. by P. Isard, A. Razin, and A. Rose, Springer, Dordrecht, chap. 5, 31-55.

Levy-Yeyati, E. And F. Sturzenegger (2005): "Classifying exchange rate regimes: deeds vs. words," European Economic Review, 49, 1603-1635. 
Macher, F. (2018): "The Hungarian twin crisis of 1931," The Economic History Review, $00,1-28$.

Maluquer de Motes, J. (2013): La inflacion en España. Un indice de precios de consumo, 1830-2012., 64, Estudios de Historia Economics, Banco de España.

Martin, A. (2009): "Reconciling Bagehot and the Fed's response to September 11," Journal of Money, Credit and Banking, 397-415.

Martín-AceñA, P. (1984): La politica monetaria en España, 1919-1935, Instituto de Estudios Fiscales.

(2006): El Banco de Francia, el BPI y la creacion del servicio de estudios del Banco de España a principos de la decada de 1930, 0602, Documentos Ocasionales, Banco de España.

Martín-Aceña, P., E. Martínez-Ruiz, And P. Nogués-Marco (2013): "Floating against the tide: Spanish monetary policy, 1870-1931," Working Papers in Economic History, Universidad Carlos III de Madrid.

Martínez Mendez, P. (1990): Nuevos datos sobre la evolucion de la peseta entre 1900 y 1936. Informacion complementaria, 9011, Servicio de Estudios del Banco de España.

- (2005): La investigacion inedita de Padro Martinez Mendez sobre el Tesoro y el Banco de España entre 1900 y 1936, Estudios de Historia Economica. Banco de España.

Martínez-Ruiz, E. And P. Nogués-Marco (2014): Crisis cambiarias y politicas de intervencion en España, 1880-1975, 66, Estudios de Historia Economica, Banco de España.

Mouré, K. (2002): The Gold Standard Illusion, Oxford University Press.

PABÓn, J. (2000): Cambó: 1876-1947, Alpha.

Prados DE la Escosura, L. (2003): El progreso economico de España (1850-2000), Fundacion BBVA.

Reinhart, C. M. And K. S. Rogoff (2009): This time is different: eight centuries of financial folly, Princeton University Press.

REy, H. (2015): "Dilemma not Trilemma: the Global Financial Cycle and Monetary Policy Independence," NBER Working Paper. 
SARDÀ, J. (1936): La intervencion monetaria y el comercio de divisas en España, Servicio de Estudios de la Banca Mas Sarda (1975 edition).

Schnabel, I. (2004): "The German twin crisis of 1931," The Journal of Economic History, $3,882-871$.

Schubert, A. (1991): The Credit-Anstalt Crisis of 1931, Cambridge University Press.

Servicio de estudios del BAnco de España (1935): Liquidez bancaria, Banco de España.

Straumann, T. (2010): Fixed ideas of money. Small states and exchange rate regimes in twentieth-century Europe, Cambridge University Press.

TAPIA, J. (1998): "La II Republica y la quimera de la peseta: la excepcion Carner," Publicaciones de la Real Academia de Ciencias Economicas y Financieras.

Temin, P. (1993): "Transmission of the Great Depression," Journal of Economic Perspectives, $7,87-102$.

_ (2008): "The German crisis of 1931: evidence and tradition," Cliometrica, 1, 5-17.

TenA, A. (2005): Sector Exterior, BBVA, chap. 8.

Toniolo, G. And P. Clement (2005): Central Bank Cooperation at the Bank for International Settlements, 1930-1973, Cambdrige: Cambridge University Press.

Tortella, G. And J. PAlafox (1984): "Banking and industry in Spain, 1918-1936," The Journal of European Economic History, 81-111.

UGolini, S. (2017): The evolution of central banking: theory and history, Palgrave Macmillan.

URBAn, S. A. (2009): "The name of the rose: classifying 1930s exchange-rate regimes," Discussion Papers in Economic and Social History, University of Oxford.

Vandellós, J. A. (1936): El porvenir del cambio de la peseta, Servicio de Estudios de la Banca Mas Sarda (1975 edition).

Velarde, J. (1968): Politica Economica de la Dictadura, Guadiana de Publicaciones.

— (1983): "Indalecio Prieto en Hacienda," Studia Historica, 53-66. 
(2015): Indalecio Prieto como gestor de la economia española, Fundacion Indalecio Prieto. Ministerio de Hacienda y Administraciones Publicas. Centro de Publicaciones., chap. 2.

Wolf, N. (2008): "Scylla and Charybdis. Explaining Europe's exit from gold, January 1928-December 1936," Explorations in Economic History, 383-401. 